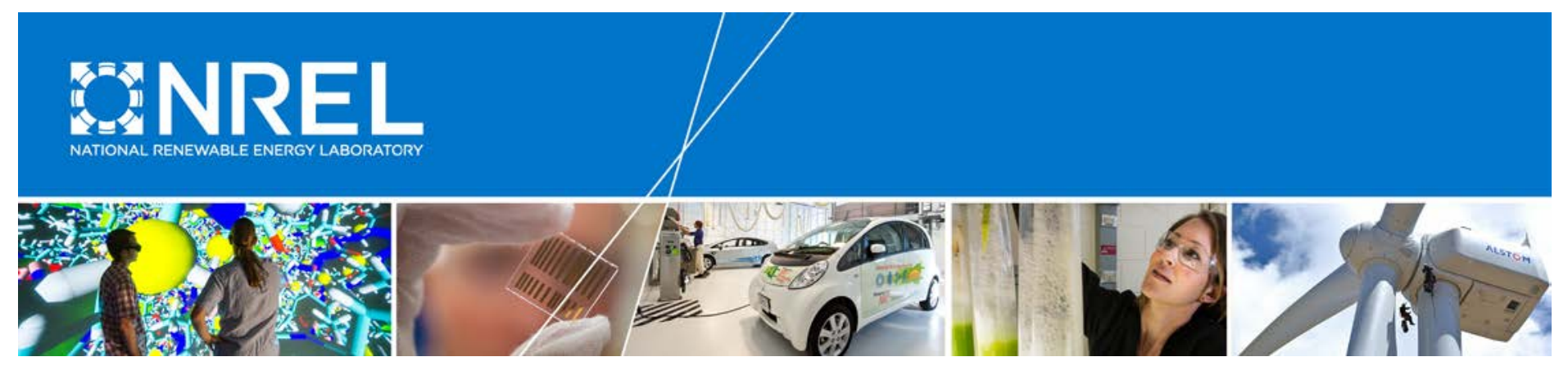

\title{
The Solar Access to Public Capital (SAPC) Mock Securitization Project
}

Michael Mendelsohn and Travis Lowder National Renewable Energy Laboratory

Mary Rottman

Rottman-Associates

Ronald Borod

DLA Piper

Nathan Gabig, Stephen Henne, and

Conrad Caplin

KPMG

Quentin Notte

Mercatus

NREL is a national laboratory of the U.S. Department of Energy Office of Energy Efficiency \& Renewable Energy Operated by the Alliance for Sustainable Energy, LLC

This report is available at no cost from the National Renewable Energy Laboratory (NREL) at www.nrel.gov/publications.

Technical Report

NREL/TP-6A20-64347

December 2015

Contract No. DE-AC36-08GO28308 


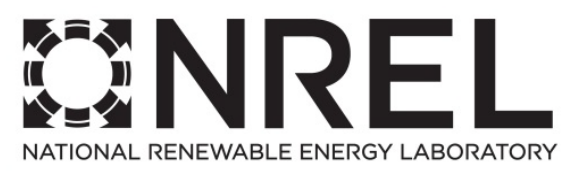

\section{The Solar Access to Public Capital (SAPC) Mock Securitization Project}

Michael Mendelsohn and Travis Lowder National Renewable Energy Laboratory

Mary Rottman

Rottman-Associates

Ronald Borod DLA Piper

Nathan Gabig, Stephen Henne, and Conrad Caplin KPMG

\section{Quentin Notte}

Mercatus

Prepared under Task No. SM13.1030

NREL is a national laboratory of the U.S. Department of Energy Office of Energy Efficiency \& Renewable Energy Operated by the Alliance for Sustainable Energy, LLC

This report is available at no cost from the National Renewable Energy Laboratory (NREL) at www.nrel.gov/publications.

National Renewable Energy Laboratory 15013 Denver West Parkway Golden, CO 80401

303-275-3000 • www.nrel.gov
Technical Report

NREL/TP-6A20-64347

December 2015

Contract No. DE-AC36-08G028308 


\title{
NOTICE
}

This report was prepared as an account of work sponsored by an agency of the United States government. Neither the United States government nor any agency thereof, nor any of their employees, makes any warranty, express or implied, or assumes any legal liability or responsibility for the accuracy, completeness, or usefulness of any information, apparatus, product, or process disclosed, or represents that its use would not infringe privately owned rights. Reference herein to any specific commercial product, process, or service by trade name, trademark, manufacturer, or otherwise does not necessarily constitute or imply its endorsement, recommendation, or favoring by the United States government or any agency thereof. The views and opinions of authors expressed herein do not necessarily state or reflect those of the United States government or any agency thereof.

This report is available at no cost from the National Renewable Energy Laboratory (NREL) at www.nrel.gov/publications.

Available electronically at SciTech Connect http:/www.osti.gov/scitech

Available for a processing fee to U.S. Department of Energy and its contractors, in paper, from:

\author{
U.S. Department of Energy \\ Office of Scientific and Technical Information \\ P.O. Box 62 \\ Oak Ridge, TN 37831-0062 \\ OSTI http://www.osti.gov \\ Phone: 865.576.8401 \\ Fax: 865.576.5728 \\ Email: reports@osti.gov
}

Available for sale to the public, in paper, from:

\author{
U.S. Department of Commerce \\ National Technical Information Service \\ 5301 Shawnee Road \\ Alexandria, VA 22312 \\ NTIS http://www.ntis.gov \\ Phone: 800.553 .6847 or 703.605 .6000 \\ Fax: 703.605.6900 \\ Email: orders@ntis.gov
}




\section{Acknowledgments}

The authors and the Solar Access to Public Capital (SAPC) working group are heavily indebted to its many members who participated directly or indirectly in the mock securitization process. The authors would like to provide a special thanks to Melanie Gnazzo of Chapman and Cutler LLP for co-developing with Ron Borod of DLA Piper LLP the proposed legal structure and drafting the proposed term sheet for the Tandem Tax Equity-Securitization mock transaction, and John Joshi of Capital Fusion Partners (and now NYSERDA) for a wide variety of data gathering and organizational leadership. Additional thanks to Forrest Milder of Nixon Peabody LLP; Chris D'Angelo and Brandon Hadley of Katten Muchin Rosenman LLP; David Ridenour of Orrick, Herrington \& Sutcliffe LLP; and David Sykes, formerly of Kilowatt Financial (now at Renew Financial) for their contributions and insights that have helped to shape the structure and terms for the Tandem Tax Equity-Securitization mock transaction; and to Larrs Norell and Abhi

Parmer of Altus Power America for providing project data, cash flows, and analytical support for the Tandem Tax Equity-Securitization mock transaction and Mike McGuire of Wiser Capital for modeling the liability structure of the transaction. Lastly, thank you to all the independent engineering (IE) firms that provided technical feedback regarding asset management and portfolio due diligence, including: Black \& Veatch, DNVGL, Leidos, TÜV Rheinland, and VDE. Special thanks to Paul Detering of Redwood Insights for leading an IE subcommittee, and Sarah Kurtz of NREL for additional technical contributions.

The authors and all of SAPC would like to provide a special thanks to the ratings agencies and the associated personnel who contributed invaluable time to improve the efficacy of the process for rating solar portfolios and who provided their perspectives on solar as a ratable asset class. We greatly appreciate the time and energy of Hector Campos, Winston Chang, Xilun Chen, and Trevor D'Olier-Lees, of Standard \& Poor's; Chuck Weilamann and Chris O'Connell from DBRS; Andrew Giudici, Lenny Giltman, and Glenn Costello from Kroll Bond Ratings Agency (KBRA); Wendy Cohn and Michael Dean from Fitch Ratings; and Moody's Investor Service.

The term sheets and diagrams for the mock Residential Solar and Tandem Tax EquitySecuritization transactions have been reviewed by a broad spectrum of players in the solar, finance, accounting, and legal professions, and we would like to express our gratitude to these additional reviewers for their feedback and for having taken such a keen interest in our activities. We are releasing these documents to the public so that issuers, counsel, ratings agencies, underwriters, investors, and other stakeholders may make use of them to inform their own decision-making and to drive growth in the solar asset class. 


\section{Acronyms}

\begin{tabular}{|c|c|}
\hline ABS & asset-backed securities \\
\hline ASDAB & average solar discounted asset balance \\
\hline C\&I & commercial and industrial \\
\hline CMBS & commercial mortgage-backed securities \\
\hline DOE & U.S. Department of Energy \\
\hline DSCR & debt service coverage requirement \\
\hline FHLMC & $\begin{array}{l}\text { Federal Home Loan Mortgage Corporation } \\
\text { ("Freddie Mac") }\end{array}$ \\
\hline $\mathrm{FICO}$ & Fair Isaac Corporation \\
\hline FNMA & $\begin{array}{l}\text { Federal National Mortgage Association ("Fannie } \\
\text { Mae") }\end{array}$ \\
\hline GNMA & $\begin{array}{l}\text { Governmental National Mortgage Association } \\
\text { ("Ginnie Mae") }\end{array}$ \\
\hline GSE & government-sponsored entity \\
\hline IE & independent engineering \\
\hline IRR & internal rate of return \\
\hline ITC & investment tax credit \\
\hline KBRA & Kroll Bond Ratings Agency \\
\hline LLC & limited liability company \\
\hline LLP & limited liability partnership \\
\hline MBS & mortgage-backed securities \\
\hline NREL & National Renewable Energy Laboratory \\
\hline NYSERDA & $\begin{array}{l}\text { New York State Energy Research and Development } \\
\text { Agency }\end{array}$ \\
\hline O\&M & operations and maintenance \\
\hline $\mathrm{OCV}$ & original contract value \\
\hline PPA & power purchase agreement \\
\hline PV & photovoltaics \\
\hline QIB & qualified institutional buyer \\
\hline S\&P & Standard \& Poor's \\
\hline SAPC & Solar Access to Public Capital \\
\hline sf & structured finance \\
\hline SIFMA & $\begin{array}{l}\text { Securities Industry and Financial Markets } \\
\text { Association }\end{array}$ \\
\hline SPV & special purpose vehicle \\
\hline SREC & solar renewable energy credit \\
\hline UPB & unpaid principal balance \\
\hline
\end{tabular}




\section{Executive Summary}

In late 2012, the National Renewable Energy Laboratory (NREL) initiated the Solar Access to Public Capital (SAPC) working group. Backed by a three-year funding facility from the U.S. Department of Energy (DOE), NREL set out to organize the solar, legal, banking, capital markets, engineering, and other relevant stakeholder communities in order to open lower-cost debt investment for solar asset deployment. SAPC engaged its members to standardize contracts, develop best practices, and comprehend how the rating agencies perceive solar project portfolios as an investment asset class. Rating agencies opine on the future creditworthiness of debt obligations. Issuers often seek investment-grade ratings from the rating agencies in order to satisfy the desires of their investors. Therefore, for the solar industry to access larger pools of capital at a favorable cost, it is critical to increase market participants' understanding of solar risk parameters.

However, SAPC members quickly recognized the difficulties in gleaning insight from the rating agencies through conceptual discussion alone. Instead, to provide their perspective on technological and credit-related risk factors, rating agencies would need to evaluate a proposed asset-backed security transaction, or something that very closely approximates a proposed assetbacked security being offered in the marketplace. Accordingly, SAPC members set out to develop "mock" or hypothetical portfolios of solar assets, with highly detailed - and potentially replicable - deal-structures term sheets, cash-flow analytics, and other components of a structured finance issuance, just as rating agencies commonly see when rating various ABS deals such as auto loans, mortgages, or equipment leases.

The process provided valuable information to address rating agency perceptions of risk that, without such information, could require costly credit enhancement or higher yields to attract institutional investors. Two different securities were developed - one for a hypothetical residential solar portfolio and one for a hypothetical commercial solar portfolio. Five rating agencies (Standard and Poor's, Moody's, KBRA, Fitch, and DBRS) participated and provided extensive feedback, some through conversations that extended several months. The findings represented in this report are a composite summary of that feedback and do not indicate any specific feedback from any single rating agency. Table ES-1 offers a summary tabulation of these findings. 
Table ES-1. Summary of Ratings Agency Feedback on the SAPC Mock Securitization Process

\begin{tabular}{|c|c|c|c|}
\hline \multicolumn{2}{|r|}{ Feedback } & Issue & $\begin{array}{c}\text { Potential Action Steps by SAPC } \\
\text { and Market Participants }\end{array}$ \\
\hline 1. & $\begin{array}{l}\text { Lack of } \\
\text { performance data }\end{array}$ & $\begin{array}{l}\text { - Limited solar production and } \\
\text { customer credit performance } \\
\text { data to estimate losses }\end{array}$ & $\begin{array}{l}\text { - Compile at least } 3-5 \text { years of } \\
\text { data on a meaningful sample of } \\
\text { systems and contracts } \\
\text { - Promote adoption of standard } \\
\text { contracts and system } \\
\text { performance measurements } \\
\text { - Establish uniform data- } \\
\text { collection procedures and data } \\
\text { bases }\end{array}$ \\
\hline 2. & $\begin{array}{l}\text { Issuer business- } \\
\text { model risk: } \\
\text { - Vertically vs. } \\
\text { non-vertically } \\
\text { integrated }\end{array}$ & $\begin{array}{l}\text { - Control and quality standards } \\
\text { - Vertically integrated } \\
\text { companies may reduce risk } \\
\text { by controlling all aspects of } \\
\text { customer acquisition, system } \\
\text { design, installation and } \\
\text { operations and maintenance } \\
\text { (O\&M), billing and payment } \\
\text { processing, and investor } \\
\text { reporting } \\
\text { - Non-vertically integrated } \\
\text { companies may add risk if } \\
\text { critical functions are } \\
\text { outsourced and controls and } \\
\text { quality standards are not } \\
\text { enforced }\end{array}$ & $\begin{array}{l}\text { - Issuer/developers benefit from } \\
\text { clearly defining and } \\
\text { communicating the } \\
\text { effectiveness of their business } \\
\text { model in managing and } \\
\text { enforcing quality standards and } \\
\text { business practices, addressing } \\
\text { how risk from third-party } \\
\text { vendors is mitigated } \\
\text { - More industry information } \\
\text { needed to be able to identify } \\
\text { and quantify increased } \\
\text { operational risk in non-vertically } \\
\text { integrated business models }\end{array}$ \\
\hline 3. & $\begin{array}{l}\text { Customer value } \\
\text { proposition for } \\
\text { third-party solar } \\
\text { contracts }\end{array}$ & $\begin{array}{l}\text { Customers may perceive } \\
\text { greater value in new contracts } \\
\text { offering greater savings, } \\
\text { which could increase defaults, } \\
\text { payment delays, and contract } \\
\text { re-negotiations } \\
\text { - Customer contract terms vary } \\
\text { by region and developer } \\
\text { - What assumptions are used } \\
\text { for energy costs over time } \\
\text { What assumptions are used } \\
\text { for PV panel degradation }\end{array}$ & $\begin{array}{l}\text { - Transparency in customer } \\
\text { acquisition process and contract } \\
\text { assumptions } \\
\text { - Adoption of industry-created } \\
\text { standard contracts with } \\
\text { standard terms and conditions } \\
\text { - Greater standardization and } \\
\text { adoption of energy cost } \\
\text { production and savings } \\
\text { methodology } \\
\text { - Shorter lease/contract terms }\end{array}$ \\
\hline & $\begin{array}{l}20 \text {-year contract } \\
\text { terms }\end{array}$ & $\begin{array}{l}\text { - Long contract terms introduce } \\
\text { too much uncertainty } \\
\text { - Energy and regulatory } \\
\text { landscape expected to } \\
\text { change dramatically } \\
\text { - Unable to reasonably predict } \\
\text { or quantify impact on payment } \\
\text { performance }\end{array}$ & $\begin{array}{l}\text { - If possible, shorten the length of } \\
\text { contract terms } \\
\text { - Structure securitization debt } \\
\text { with shorter maturity ( } 7-10 \mathrm{yrs} \text { ) }\end{array}$ \\
\hline
\end{tabular}




\begin{tabular}{|c|c|c|c|}
\hline & Feedback & Issue & $\begin{array}{c}\text { Potential Action Steps by SAPC } \\
\text { and Market Participants }\end{array}$ \\
\hline & $\begin{array}{l}\text { Value of } \\
\text { equipment } \\
\text { warranty }\end{array}$ & $\begin{array}{l}\text { - Manufacturer warranty } \\
\text { obligations cannot be valued } \\
\text { in a securitization } \\
\text { - Most manufacturers are not } \\
\text { rated and no credit is given to } \\
\text { payment obligations } \\
\text { - Warranty terms vary by } \\
\text { manufacturer and equipment } \\
\text { type } \\
\text { - Not feasible to assess various } \\
\text { warranty coverages for every } \\
\text { system in a securitization pool }\end{array}$ & $\begin{array}{l}\text { - Quantify risk and establish } \\
\text { reserve fund in securitization to } \\
\text { cover potential expense }\end{array}$ \\
\hline 6. & $\begin{array}{l}\text { Operations and } \\
\text { maintenance of } \\
\text { systems in } \\
\text { securitized pool }\end{array}$ & $\begin{array}{l}\text { - Is the O\&M provider a rated } \\
\text { and creditworthy entity? } \\
\text { - If not, what happens if O\&M } \\
\text { provider fails to perform? } \\
\text { - How will the systems be } \\
\text { monitored and maintained? } \\
\text { - What companies exist with a } \\
\text { national footprint and } \\
\text { financially capable of } \\
\text { assuming these } \\
\text { responsibilities? } \\
\text { - What is the cost of transition } \\
\text { and the ongoing } \\
\text { maintenance? } \\
\text { - Can the securitization cash } \\
\text { flows support these costs? }\end{array}$ & $\begin{array}{l}\text { - More emphasis on identifying } \\
\text { O\&M service providers that } \\
\text { meet credit market standards } \\
\text { - Adoption of O\&M best practices } \\
\text { and standards } \\
\text { - More cost transparency by } \\
\text { participating in industry O\&M } \\
\text { databases and cost calculators } \\
\text { - Structure securitizations to } \\
\text { include market rate fees for } \\
\text { O\&M services and specific } \\
\text { procedures for back-up O\&M } \\
\text { providers }\end{array}$ \\
\hline 7. & $\begin{array}{l}\text { Inverter } \\
\text { replacement and } \\
\text { performance }\end{array}$ & $\begin{array}{l}\text { What are the assumptions } \\
\text { about inverter replacement } \\
\text { timing and cost? } \\
\text { - What types of inverters are in } \\
\text { the pool? } \\
\text { What manufacturers are } \\
\text { represented? } \\
\text { Are securitization cash flows } \\
\text { sufficient to pay for inverter } \\
\text { replacement? }\end{array}$ & $\begin{array}{l}\text { - Increase transparency about } \\
\text { inverter technology and } \\
\text { performance } \\
\text { - Establish standard performance } \\
\text { and cost measurements to } \\
\text { facilitate quantifying cost for } \\
\text { securitizations } \\
\text { - Securitization structure provides } \\
\text { cash flow and reserves for } \\
\text { inverter replacement and other } \\
\text { O\&M expenses not paid by } \\
\text { O\&M provider sufficient to } \\
\text { replace inverters according to a } \\
\text { conservative schedule based on } \\
\text { credible data for each type and } \\
\text { manufacturer }\end{array}$ \\
\hline
\end{tabular}




\begin{tabular}{|c|c|c|}
\hline Feedback & Issue & $\begin{array}{c}\text { Potential Action Steps by SAPC } \\
\text { and Market Participants }\end{array}$ \\
\hline $\begin{array}{l}\text { 8. System equipment } \\
\text { quality and } \\
\text { performance } \\
\text { reliability }\end{array}$ & $\begin{array}{l}\text { - Securitization pool systems } \\
\text { built with equipment from } \\
\text { different manufacturers and } \\
\text { potentially different installation } \\
\text { procedures } \\
\text { - Limited standards or quality- } \\
\text { assessment rating for PV } \\
\text { panels } \\
\text { - Installation practices vary and } \\
\text { may reduce equipment } \\
\text { performance } \\
\text { - Manufacturer warranty may } \\
\text { not pay for total cost of labor } \\
\text { and replacement }\end{array}$ & $\begin{array}{l}\text { - Prepare a detailed report } \\
\text { outlining manufacturers and } \\
\text { equipment selection process } \\
\text { - Standardize O\&M process and } \\
\text { provide reporting and } \\
\text { documentation } \\
\text { - Validate equipment output, } \\
\text { performance rating, and track } \\
\text { record } \\
\text { - Establish experience of and } \\
\text { credit quality of manufacturers } \\
\text { - Use insurance products to } \\
\text { cover manufacturer warranty } \\
\text { obligation and potential cash- } \\
\text { flow shortfall to the investors } \\
\text { - Establish reserve fund to cover } \\
\text { potential cash-flow shortfalls }\end{array}$ \\
\hline $\begin{array}{l}\text { 9. Role of } \\
\text { independent } \\
\text { engineering firms } \\
\text { in securitization } \\
\text { analysis }\end{array}$ & $\begin{array}{l}\text { - Industry and business models } \\
\text { in solar are too young and } \\
\text { rapidly evolving to rely on } \\
\text { standard asset due-diligence } \\
\text { techniques. } \\
\text { - A comprehensive } \\
\text { independent engineering due- } \\
\text { diligence report is needed to } \\
\text { identify and quantify risks for } \\
\text { securitization cash-flow } \\
\text { analysis }\end{array}$ & $\begin{array}{l}\text { Promote transparency in all } \\
\text { aspects of solar value chain } \\
\text { starting from the equipment } \\
\text { manufacturing through asset } \\
\text { and customer management } \\
\text { - Work with the IE community to } \\
\text { standardize system } \\
\text { performance measurements } \\
\text { and promote industry best } \\
\text { practices to build credibility for } \\
\text { using statistical sampling due- } \\
\text { diligence practices }\end{array}$ \\
\hline $\begin{array}{l}\text { 10. Credit } \\
\text { enhancement }\end{array}$ & $\begin{array}{l}\text { - Is overcollateralization the } \\
\text { only available source of credit } \\
\text { enhancement for a solar } \\
\text { securitization? }\end{array}$ & $\begin{array}{l}\text { Promote development of } \\
\text { alternative sources of credit } \\
\text { enhancement in the insurance } \\
\text { and financial services industries }\end{array}$ \\
\hline $\begin{array}{l}\text { 11. Tax-equity } \\
\text { investors and } \\
\text { securitization }\end{array}$ & $\begin{array}{l}\text { Can securitization and tax } \\
\text { equity co-exist in financing a } \\
\text { pool of solar assets? } \\
\text { Does the securitization } \\
\text { increase the risk of recapture } \\
\text { for the tax-equity investor? } \\
\text { Do the securitization investors } \\
\text { have the same security } \\
\text { interest and protection they } \\
\text { would have in financing } \\
\text { without tax equity? }\end{array}$ & $\begin{array}{l}\text { By using certain legal structures } \\
\text { for the tax-equity investment } \\
\text { and the securitization, tax equity } \\
\text { and securitization can co-exist } \\
\text { in financing a pool of } \\
\text { commercial solar assets (see } \\
\text { link to tandem tax-equity and } \\
\text { securitization term sheet) }\end{array}$ \\
\hline
\end{tabular}




\section{Feedback}

12. Cash-flow modeling

\section{Issue}

- Devising cash-flow modeling for new or esoteric asset classes includes input from and analysis performed by leading independent engineering firm(s). A meaningful independent IE report on a hypothetical solar portfolio and transaction structure was not possible.
Potential Action Steps by SAPC and Market Participants

- Be prepared for and have available detailed due-diligence analysis and reports to inform rating agencies about the issuer/sponsor's business model and value proposition, customer acquisition, underwriting and origination process

- Solar system design, equipment, and quality control and historical performance statistics about energy output compared to expected output, energy contract payment experience and statistics

- O\&M process, experience and costs

- Other asset-management and risk-mitigation processes and procedures. 


\section{Table of Contents}

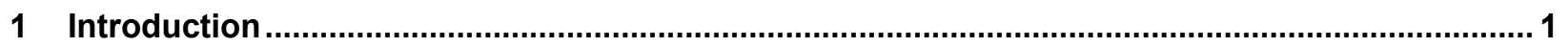

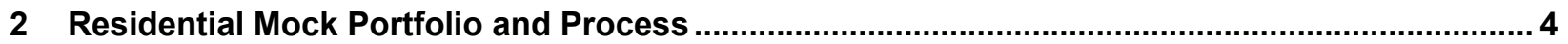

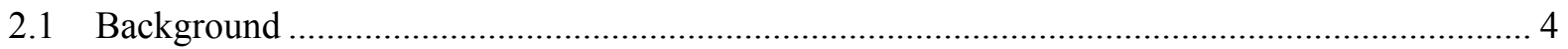

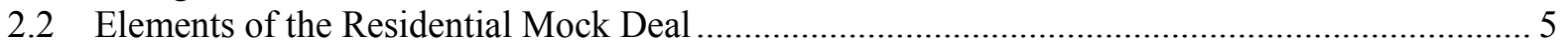

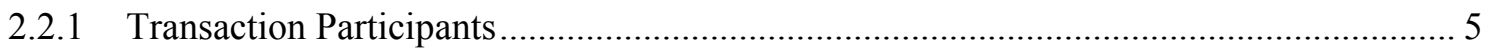

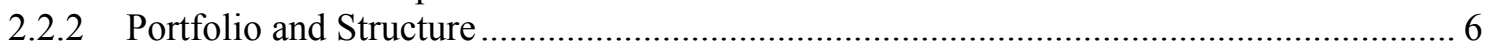

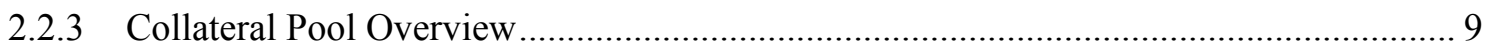

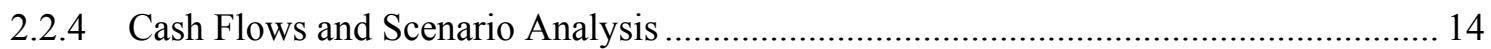

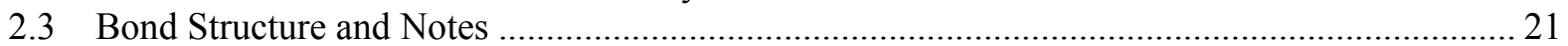

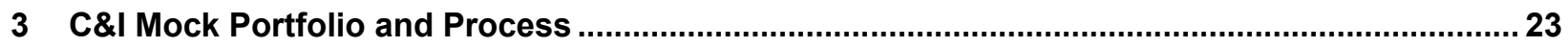

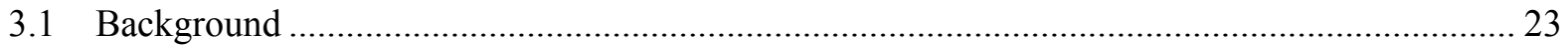

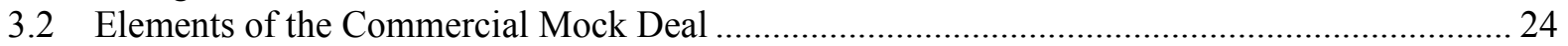

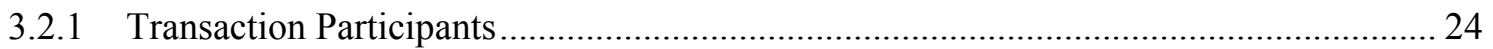

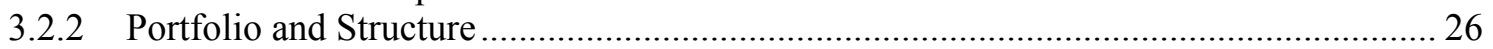

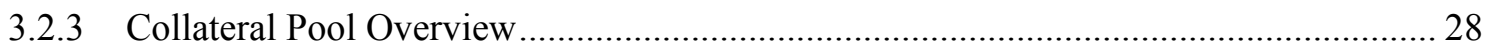

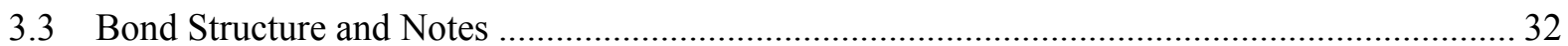

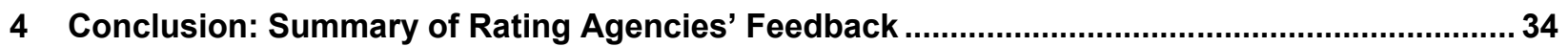

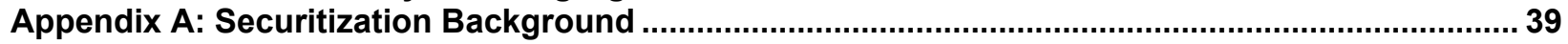

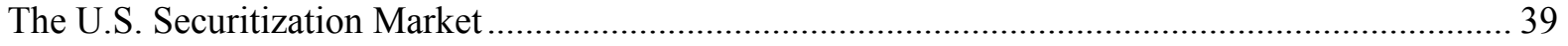

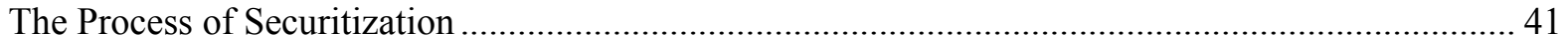

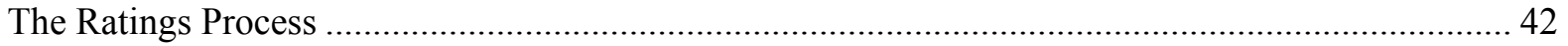




\section{Figures and Tables}

Figure 1. Residential securitization legal structure ........................................................................ 7

Figure 2. Residential securitization flow of funds diagram ........................................................ 8

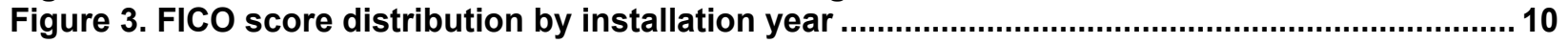

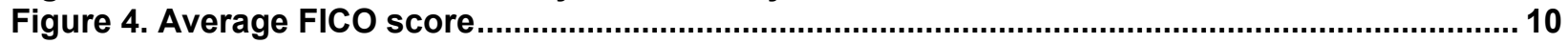

Figure 5. (a) SunCurve 2x scenario cash flows; (b) SunCurve $2 x$ scenario residual payments....... 19

Figure 6. (a) Cumulative Loss Front-Loaded scenario cash flows; (b) 4\% Cumulative Loss Front-

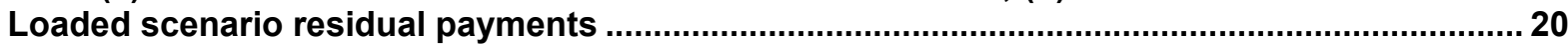

Figure 7. (a) The Technological Evolution scenario cash flows; (b) Technological Evolution

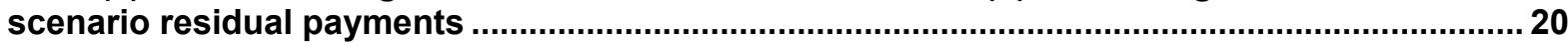

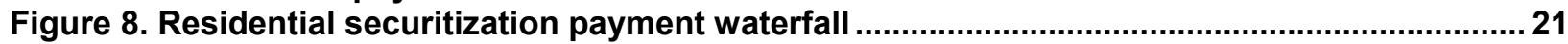

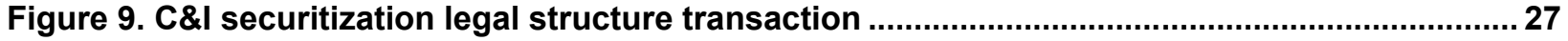

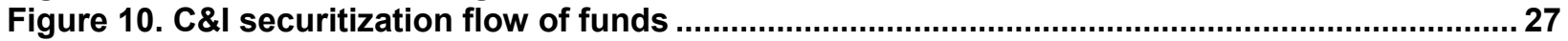

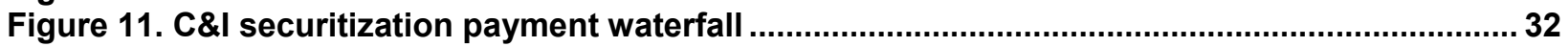

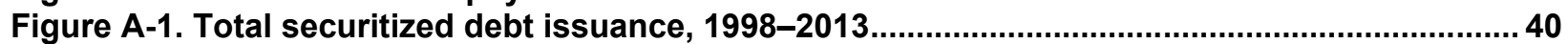

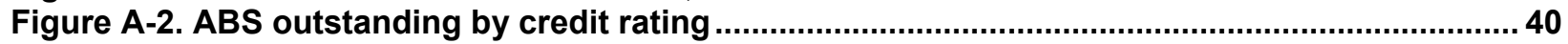

Table ES-1. Summary of Ratings Agency Feedback on the SAPC Mock Securitization Process..... vi

Table 1. Diversity and Background of Residential Pool ................................................................... 6

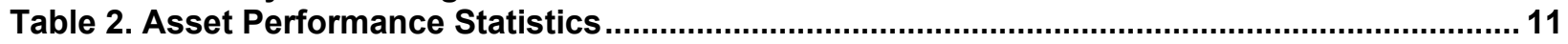

Table 3. Asset Performance Characteristics................................................................................. 13

Table 4. Scenarios Presented to Rating Agencies ...................................................................... 17

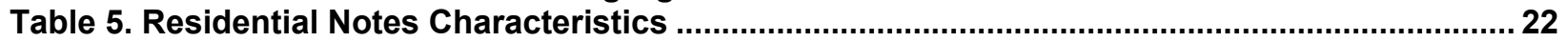

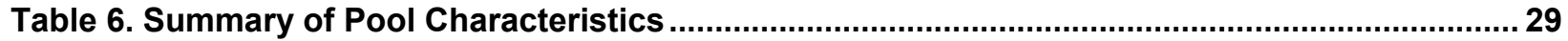

Table 7. SolarCo 2014-2 Project Size Stratification ............................................................................. 29

Table 8. SolarCo 2014-2 Starting Price for Delivered Power Stratification ....................................... 29

Table 9. SolarCo 2014-2 Project Portfolio Geographic Diversity .......................................................... 30

Table 10. SolarCo 2014-2 Stratification of the Off-Taker Credit Rating........................................... 30

Table 11. SolarCo 2014-2 Duration of SREC Contracts ....................................................................... 31

Table 12. SolarCo 2014-2 Distribution of Source of Solar Panels by Manufacturer .......................... 31

Table 13. Summary of Hypothetical Notes Issued in C\&I Transaction.............................................. 32

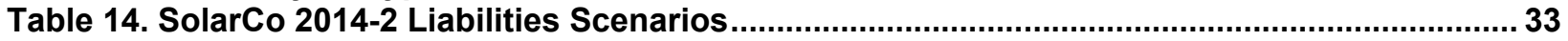

Table 15. Summary of SolarCity and Sunrun Securitizations ...................................................... 34

Table 16. Summary of Ratings Agency Feedback on the SAPC Mock Securitization Process........ 35 


\section{Introduction}

For the past decade, renewable energy projects have been identified as an esoteric asset class with the potential for securitization. They possess the requisite features of contractual cash flows from leases and power purchase agreements, scalability, high capital requirements, and unrated sponsors and developers that are attracted to the lower financing costs of securitization. ${ }^{1}$

However, despite a decade's worth of interest, renewable energy sponsor/developer access to the capital markets through securitization has proven more difficult than anticipated. Barriers to entry have included:

1. Market fragmentation among small developers. This fragmentation was only recently addressed in the residential solar space with the emergence of several companies with substantial residential solar portfolios (e.g., SolarCity, Sunrun, and others);

2. Lack of historical financial and operational data. This made it difficult for rating agencies to assess the reliability of projected cash flows over the bond time horizon;

3. Resistance of tax-equity investors to the transfer of the solar assets into a securitization vehicle and the pledge of such assets to secure the debt securities. Approval of tax-equity investors is normally required for such transfers, and they are typically resistant due to the recapture risk that such transfers and pledges create, as well as the reluctance of tax equity to cede certain control rights to an indenture trustee or a noteholder representative.

Viewed against this background, it is no surprise that the solar industry has historically been financed by relatively expensive project finance capital, primarily in the form of equity, including both tax equity and cash equity. Where leverage is used, it is typically limited to $50 \%$ or less of the solar asset collateral value.

In 2012, the National Renewable Energy Laboratory (NREL) received a three-year grant from the Department of Energy's SunShot Initiative to organize a broad array of stakeholders and facilitate wide-scale investment in the solar asset class - in particular, using lower-cost debt instruments such as rated asset-backed securities (ABS). With this funding, NREL convened the Solar Access to Public Capital (SAPC) working group, originally an assembly of roughly 30 leading entities in the solar, finance, legal, engineering, and accounting fields, which grew to nearly 500 entities by of July 2015. SAPC activities were designed to reduce transactional costs and allow the pooling of project cash flows into tradable securities. These activities included:

- Standardization of power purchase agreements (PPAs) and lease contracts;

- Development of best-practice protocols for photovoltaic (PV) system installation and operation and maintenance ("O\&M") in order to encourage high-quality system deployment and operation that may improve lifetime project energy production;

\footnotetext{
${ }^{1}$ The fact that renewable energy projects depend on the performance of the sponsors or third-party service providers under Master Management or operating Maintenance Agreements was not seen as an impediment; whole-business securitizations were already being successfully rated and marketed to investors, and the management functions for solar are "light-touch" compared to those of whole-business securitizations.
} 
- Development of payment and performance data sets to facilitate investor and rating agency analysis.

One critical goal of SAPC was to facilitate a better understanding of the perspectives of rating agencies. A second critical goal was to accelerate the learning curve of the rating agencies and other market participants with respect to the solar sector by providing them access to payment and performance data and structural solutions to risks inherent in solar assets. Generally, a high (investment-grade) rating by rating agencies increases the level of investor confidence in the underlying investment, thus effectuating access to the capital markets at lower yields and thereby increasing liquidity in the solar sector.

Shortly after the formation of the working group, several of the leading rating agencies participated in a SAPC meeting to discuss their perspectives on the solar asset class. Their consistent response to questions posed was that they would be unable to give meaningful feedback in a theoretical context; instead, their most useful and reliable feedback would depend on the specifics of a particular securitization transaction. Thus, a "mock" or hypothetical securitization process was conceived as a means to solicit meaningful and actionable feedback from rating agencies that could be shared with the solar community. The exercise was intended to produce a two-fold benefit: 1) accelerate the agencies' knowledge and understanding of this new asset class, and 2) inform the solar industry about the ratings process. Ultimately, the goal was to shorten the timeline for obtaining ratings (thus reducing transaction costs) on possibly more-favorable terms for solar securitization issuers.

Similar to a real securitization, the mock filing included legal term sheets and granular cash-flow analyses of fictional solar asset portfolios for rating agencies to discuss and evaluate. Although purely hypothetical, the underlying "story" of the various entities involved in the securitizationand the projects that represented the underlying portfolio (or "securitization collateral")-were based on actual entities and project development activities in the solar industry.

Dozens of SAPC members and five rating agencies - Standard \& Poor's, Moody's, DBRS, Kroll Bond Ratings Agency (KBRA), and Fitch Ratings - participated directly in the mock securitization process. The process required extensive analysis of the simulated solar portfolios and detailed review of the proposed legal structure and deal terms, both before and after presentation to the rating agencies. Discussions with rating agencies provided direct insight into how they assess esoteric asset classes of all kinds, and a valuable perspective on cash-flow stress cases and risk factors associated with distributed solar projects. The process also provided an excellent opportunity to educate the rating agencies on the manner in which solar assets are developed, operated, and maintained, and how various technology and servicing issues are resolved.

Two different mock filings were developed: one for a hypothetical residential solar portfolio and one for a hypothetical commercial and industrial (C\&I) solar portfolio. The mock residential securitization was envisioned as providing funds for the solar developer to buy out the tax-equity investor after the recapture period; the mock commercial securitization was structured with the tax-equity investor remaining in the structure.

Meaningful engagement with the ratings agencies required the presentation of a package of information and analysis that met the standards of a typical live deal. This package included: 
- A transaction legal term sheet that described the basic terms, legal structure, and other terms of the transaction;

- A pool of solar assets, the source of the cash flow for the securitization;

- A "data tape" organizing all the operational and financial information about each solar system in the pool;

- A pool-level cash-flow model that demonstrated, at the securitization level, a variety of cash-flow scenarios showing how the security performed under different "stress" cases;

- A bond structure that detailed the allocation of cash generated by the pool to pay the securitized notes and other deal accounts.

Presentations to rating agencies included the following primary information, generally consistent with how other asset classes are presented:

- Issuer/company overview;

- Securitization collateral pool overview: details about the characteristics and creditworthiness of the collateral;

- Historical performance data: lease contract payment history, delinquency, default and transfer information (i.e., for home sales, foreclosures, life events);

- Transaction overview and transaction mechanics;

- Methodology for proposed default/stress assumptions;

- Proposed stress mechanics.

Each presentation package was accompanied by an Appendix containing (i) a detailed term sheet describing, among other features, the legal structure, various participants in the transaction and their respective roles, structural features and terms of the notes, representations and warranties of the issuer and the sponsor, events of default and trapping events, reserve-fund requirements, debt-service coverage tests, and priority of payments of revenue collections both prior to and following an event of default, and (ii) transaction and flow-of-funds diagrams.

The following technical report provides a summary of the processes, analytics, and rating agency feedback of the two SAPC-sponsored mock filings. The two main sections, Section 2 and Section 4, discuss the process, structures, and portfolios of each of the residential and C\&I mock filings, respectively. It is worth noting that the presentation of each filing differs slightly in this report because the deal teams, objectives, and other aspects of each process varied.

Although the report has been written to appeal to a broad readership, it does make use of technical concepts and terminology that may be unfamiliar to those without capital markets experience. These readers are advised to refer to Appendix A for background on securitization markets and practices. 


\section{Residential Mock Portfolio and Process}

\subsection{Background}

For its first mock portfolio, SAPC members selected the residential sector of the solar market and decided to solicit the rating agencies' perspective on a pool of residential lease contracts, then determined to be the most common form of residential solar financing.

SAPC assembled a "deal working group" to organize the effort, much as transaction participants would in a live deal. The group comprised a team of subject matter experts in the fields of legal, tax, accounting, cash-flow modeling, solar-system development, investment banking, engineering, and due diligence. The team outlined the steps needed to execute a transaction, and prepared a project timeline and set of deliverables to complete a deal presentation for in-person meetings with the rating agencies. The goal was to listen to the ratings agencies' questions and concerns about the structure and supporting data, then provide, where possible, objective information about the solar industry in response and disseminate any feedback to the SAPC working group and other stakeholders in the solar industry.

SAPC also created a fictional developer that would serve as the originator of the solar assets called SolarCo. SolarCo was stipulated to be a midsize residential solar developer whose business model is financing and installation of PV panels on residential rooftops under 20-year lease contracts. Other company statistics include:

- Headquarters in San Francisco, California;

- 2,500 employees;

- In business since 2008, and currently operational in 10 states;

- 10,000 residential installations per year that are financed $75 \%$ through leases, $10 \%$ through PPAs, and 15\% through a direct-ownership platform;

- Year-on-year growth of $50 \%$ by number of installations and $62 \%$ by revenue;

- Not publicly traded. ${ }^{2}$

SolarCo was assumed to deploy solar assets in 10 states, with California representing the majority of deployments, followed by New Jersey and Massachusetts (see Table 2). Diversity of geographic location, off-taker creditworthiness, utility rates, and price of solar energy were based on discussions with several solar developers in SAPC. They do not represent any single developer precisely.

2 SAPC specifically posited SolarCo as a privately-held, mid-sized company because of its confidence that larger development entities - e.g. SolarCity, Sunrun, etc. - could securitize on their own without necessarily leveraging the insights generated from the SAPC mock process. 


\subsection{Elements of the Residential Mock Deal}

\subsubsection{Transaction Participants}

\section{Developer/Originator}

The Originator in the residential mock structure is a limited partnership/limited liability company ("InvestCo") whose general partner/managing member is the developer ("SolarCo"). SolarCo is a company engaged in owning solar energy systems and entering into leases and PPAs under which the solar energy produced by the solar energy systems is sold to third-party residential users located in the United States. SolarCo has established a nationwide network of service providers qualified to provide servicing, engineering, and other services with respect to solar assets and leases and PPAs with customers. SolarCo has procured tax-equity investors through InvestCo, using a partnership flip structure, under which the tax-equity investors also invest directly in InvestCo. The facts stipulated in the residential mock securitization submission include the fact that the securitization is occurring after the occurrence of the "flip date," which is the date after the investment tax credit (ITC) recapture period has expired and when the interests of the tax-equity investors in the profits and losses of InvestCo will reduce from $99 \%$ to $3 \%$ and the interest of the Developer will increase to $97 \%$. Also, on and after the flip date, SolarCo has an option to purchase the interests of the tax-equity investors in InvestCo. It is assumed that this option will be exercised, using some of the proceeds of the securitization to fund such purchase price.

\section{EquipCo}

EquipCo is a newly formed bankruptcy-remote Delaware limited liability company organized as a single-purpose entity for the purpose of acquiring the solar energy systems and other related solar assets from InvestCo. Although InvestCo will receive 100\% of the membership interests in EquipCo in exchange for the assignment of the solar assets, InvestCo will, after such transfer, assign the EquipCo interests to the Issuer, as described below, thus resulting in EquipCo being a wholly owned subsidiary of the issuer.

\section{The Issuer}

The issuer (SolarCo 2014-1 LLC) is also a newly formed bankruptcy-remote Delaware limited liability company, organized for the sole purpose of issuing the securitization notes and performing the obligations of the issuer under the trust indenture. The issuer is a wholly owned subsidiary of InvestCo, and the issuer will, in turn, own $100 \%$ of the membership interests in EquipCo.

\section{Master Servicer}

SolarCo will serve as master servicer under a master servicing agreement with EquipCo, the issuer, and the indenture trustee. SolarCo will be entitled to contract under a sub-servicing agreement with qualified service providers to serve as sub-Servicer to perform all or a part of the services to be performed by SolarCo as master servicer. The residential solar structure also contemplates a back-up servicing agreement with an identified back-up servicer, who will receive and monitor all reports relating to the performance of the solar assets and payments under the leases and PPAs. The back-up servicer will, if the indenture trustee or a noteholder majority interest determines that a servicing transition Event has occurred, assume the duties of the master servicer. 


\section{O\&M Provider}

The residential mock securitization structure assumes that SolarCo will also serve as the initial O\&M provider under an operation and maintenance agreement. Upon the occurrence of an O\&M transaction event, the transition manager (described below) will recommend one or more backup O\&M providers to replace SolarCo as the O\&M provider.

\section{Transition Manager}

The transition manager is a national bank or other creditworthy institution that is appointed at the time the securitization notes are sold. It is responsible for monitoring the performance of the manager and O\&M provider, making recommendations about the need to transition all or a portion of those services to back-up or alternate service providers, and preparing a transition plan and obtaining any necessary approvals.

\section{Indenture Trustee}

The indenture trustee is the custodian and paying agent for the securitization note holders. It will also be an institutional trustee and will perform its duties under a trust indenture, under which the collateral for the securitization is pledged, the various accounts and reserve funds are established, the payment priority (also known as "waterfall") provisions are specified, events of default and trapping events and remedies therefor are established, and other directions and provisions relative to the notes and collection of funds to pay the notes are specified.

\subsubsection{Portfolio and Structure}

The pool of assets for the residential mock filing was based on the high-level portfolio characteristics of several existing residential solar developers. Table 1 provides an overview of the geography, economics, and credit quality of the assets.

Table 1. Diversity and Background of Residential Pool

\begin{tabular}{lcccccc}
\hline State & $\begin{array}{c}\text { Count } \\
\text { of State }\end{array}$ & State \% & $\begin{array}{c}\text { Avg. } \\
\text { FICO }\end{array}$ & $\begin{array}{c}\text { Avg. Cust. Cost } \\
\text { of Solar Energy } \\
\mathbf{( \$ / k W h )}\end{array}$ & $\begin{array}{c}\text { Utility } \\
\text { Rate } \\
\mathbf{( \$ / k W h )}\end{array}$ & $\begin{array}{c}\text { Customer } \\
\text { Average Discount } \\
\text { to Utility Rate (\%) }\end{array}$ \\
AZ & 267 & 1.25 & 765 & 0.125 & 0.147 & 14.55 \\
CA & 15,726 & 73.8 & 763 & 0.222 & 0.264 & 15.77 \\
CO & 1,012 & 4.75 & 772 & 0.106 & 0.118 & 10.10 \\
DC & 2 & 0.01 & 751 & 0.088 & 0.122 & 27.26 \\
HI & 727 & 3.41 & 763 & 0.243 & 0.352 & 31.04 \\
MA & 1,377 & 6.46 & 773 & 0.124 & 0.159 & 21.89 \\
MD & 24 & 0.11 & 769 & 0.114 & 0.120 & 5.02 \\
NJ & 1,908 & 8.95 & 768 & 0.147 & 0181 & 18.70 \\
NY & 189 & 0.89 & 770 & 0.140 & 0.166 & 15.29 \\
PA & 76 & 0.36 & 765 & 0.135 & 0.145 & 7.27 \\
Grand & $\mathbf{2 1 , 3 0 8}$ & $\mathbf{1 0 0}$ & $\mathbf{7 6 5}$ & $\mathbf{0 . 2 0 2}$ & $\mathbf{0 . 2 4 3}$ & $\mathbf{1 6 . 8 1}$ \\
Total & & & & & &
\end{tabular}

${ }^{*}$ Note: grand totals for FICO, Average Customer Cost, Utility Rate, and Customer Average Discount are weighted averages.

The mock deal team made several key assumptions about the status of the tax-equity investors in the ownership structure at the time of the securitization. These assumptions were as follows: 
- Tax equity invested their capital at the time the projects were placed in service in the form of a partnership flip structure;

- Under this structure, the tax-equity investor invests in the same fictional partnership in which SolarCo invests (called "InvestCo"). During the five-year recapture period, the tax-equity investor receives an allocation of $99 \%$ of the profits and losses of the partnership, and SolarCo receives an allocation of the remaining 1\%;

- After the end of five years, the allocations flip: SolarCo receives $97 \%$ of the profits and losses, and the tax-equity investor receives $3 \%$;

- After the flip occurs, SolarCo has the option to purchase the partnership interest of tax equity at fair market value;

- The securitization occurs after the five-year recapture period and some of the securitization proceeds are used to purchase the interests of the tax-equity investor. In other words, the securitization is designed to be a source of "take-out" or refinancing for the tax-equity investment and/or other strategic equity in the capital structure. Thus, the developer-sponsor effectively purchases the tax-equity investor's interest in the partnership with the debt sourced from the transaction.

By making these assumptions, the residential solar mock rating submission avoided the problem of executing a securitization with tax equity already embedded in the capital structure of the developer-sponsor. This problem was, however, addressed head on in the C\&I mock securitization (Section 3). See Figure 1 and Figure 2 for the transaction structure and flow of funds diagrams, respectively.

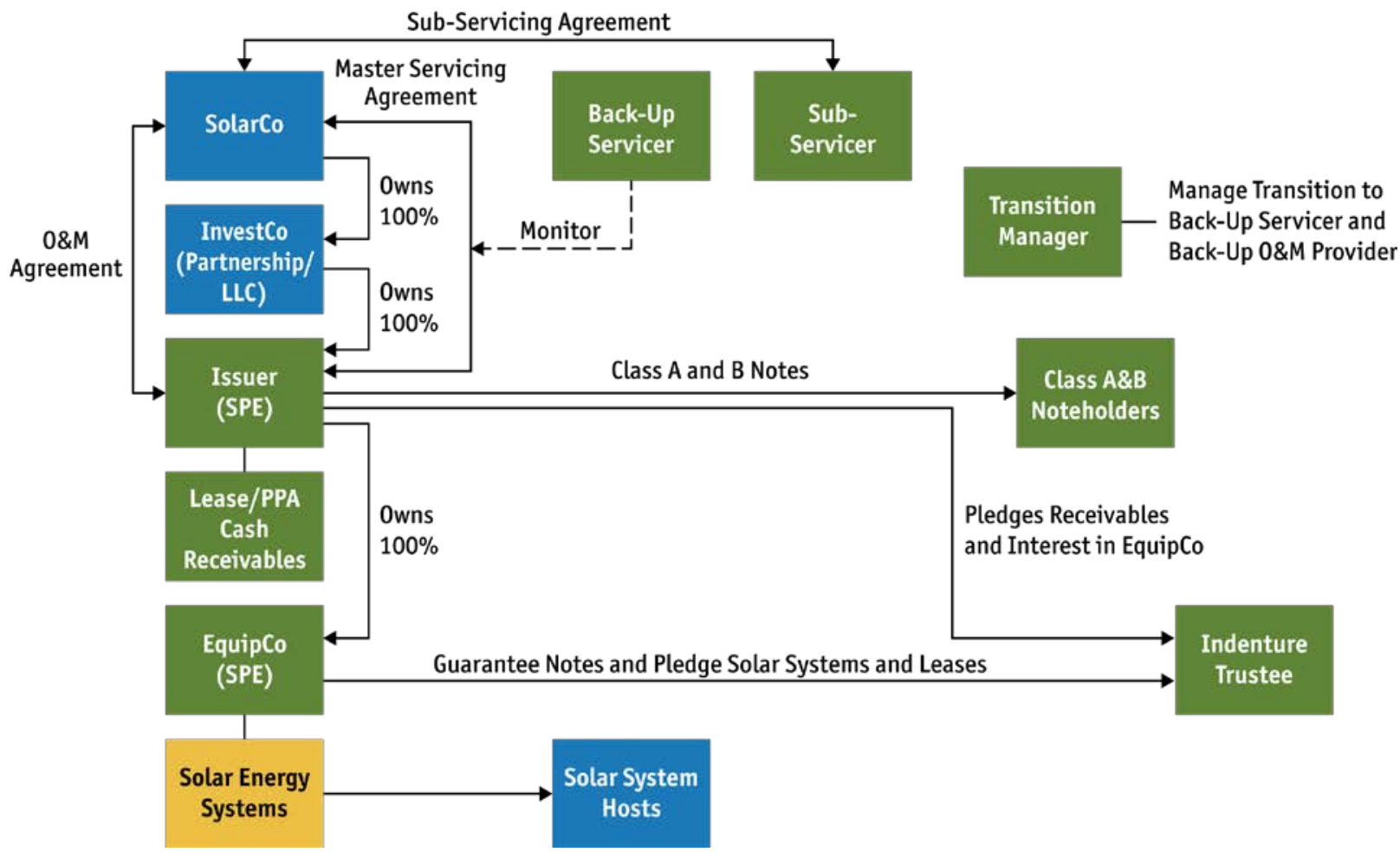

Figure 1. Residential securitization legal structure 


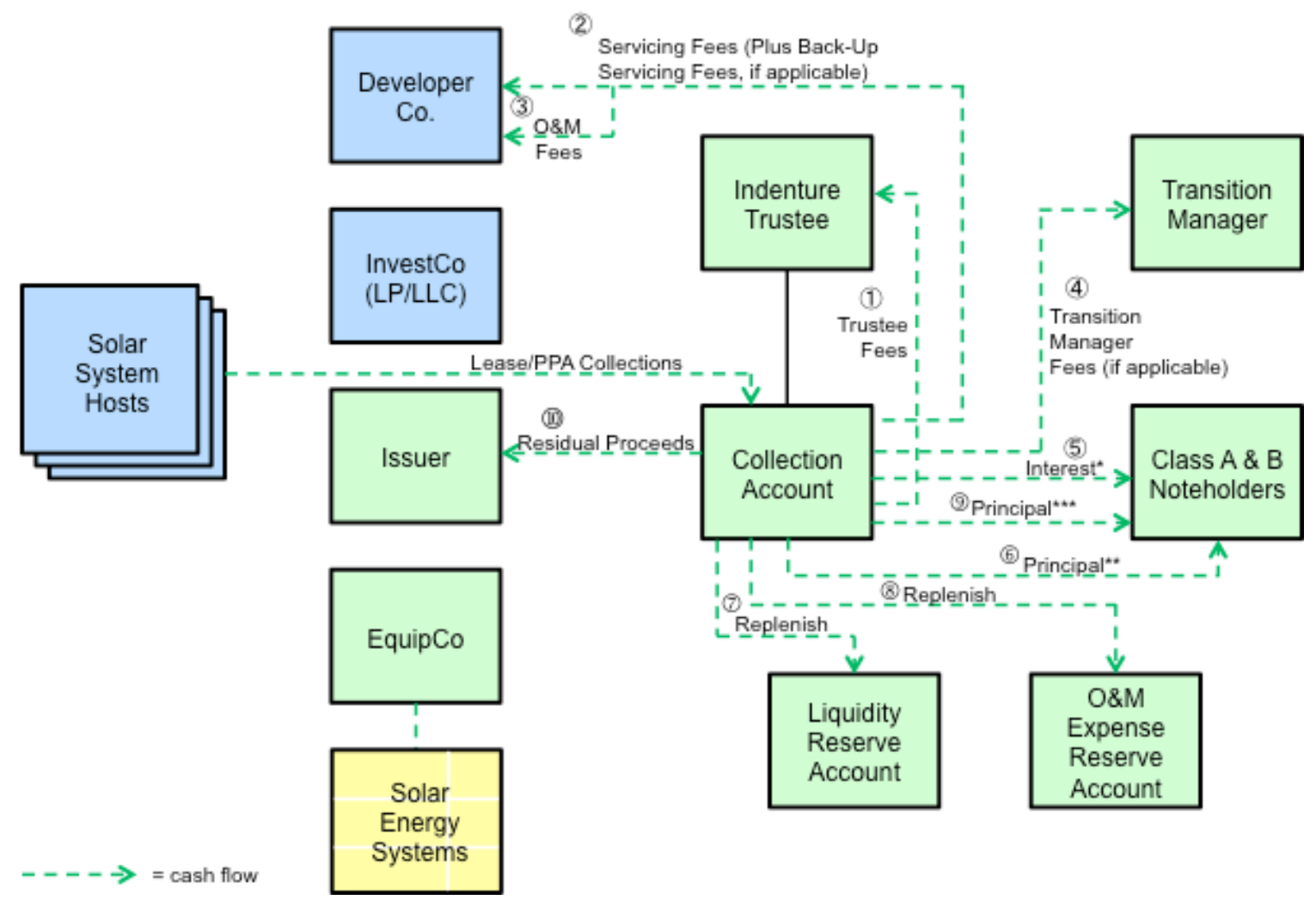

Figure 2. Residential securitization flow of funds diagram

One major strategy of the SAPC mock ratings project was to better understand the rating agency's analytical approach. Some specific examples of this strategy are as follows:

- Maximize Credit Rating: In its three presale reports regarding the first three SolarCity securitizations, ${ }^{3}$ Standard and Poor's (S\&P) announced that the highest rating attainable by the solar sector in the foreseeable future is $\mathrm{BBB}+$. Through use of senior-subordinated structures or increased overcollateralization, SAPC sought to increase the rating agency's understanding of solar as an asset class and therefore change the highest rating on the most senior tranche to $\mathrm{A}^{4}$;

- Increase Accessibility to Smaller Developers: Because only the largest solar developer has accessed the securitization market as of May 2015, SAPC focused its rating scenarios on medium-sized developer sponsors;

- Maximize Advance Rate: As of this writing, the maximum advance rate (representing the ratio of debt issued over the present value of cash flow from the underlying assets) on S\&P-rated solar securitizations was $66 \%$ for a $\mathrm{BBB}+$ rated tranche. ${ }^{5}$ The advance rate for

\footnotetext{
${ }^{3}$ S\&P (Standard and Poor's). 2013. SolarCity LMC Series I LLC (Series 2013-1); S\&P (Standard and Poor's). 2014. SolarCity LMC Series II LLC (Series 2014-1); S\&P (Standard and Poor's). 2014. SolarCity LMC Series III LLC (Series 2014-2).

${ }^{4}$ The Sunrun Inc.-sponsored securitization which closed in July 2015 received an A rating from KBRA on its senior class of notes. SolarCity LMC Series IV, LLC, Series 2015-1, which closed in August 2015, also received an A rating from KBRA on its senior notes.

${ }^{5}$ S\&P. 2014. SolarCity LMC Series III LLC (Series 2014-2). The advance rate is the inverse of overcollateralization
} 
the Senior Notes rated A (sf) by KBRA for the Sunrun-sponsored securitization that closed in July 2015 was $68.26 \% .{ }^{6}$ The advance rate for the senior notes rated A (sf) by KBRA for the SolarCity-sponsored securitization that closed in August 2015 was $56.87 \%$. The advance rate for the combined senior and subordinated notes (rated BBB (sf) by KBRA) for the Sunrun securitization was $75.77 \%$; and the advance rate for the combined senior and subordinated notes (rated BBB (sf) by KBRA) for the latest SolarCity securitization was $67.86 \%{ }^{7}$ Because of the high cost of equity for mediumsized developers, SAPC attempted to increase the advance rate for investment-grade securities and thus reduce the equity requirements for the projects;

- Optimize O\&M Expense Reserve Fund Requirements: Funding of O\&M expense reserve and replenishment of reserve over the life of securities may constitute a drag on cost of funds for issuers. Therefore, in its residential ratings submission, SAPC attempted to rationalize the O\&M expense reserve initial deposit and replenishment requirements based on actual experience of inverter replacement and other O\&M costs;

- Increase Principal Amortization Flexibility: SAPC also attempted in its rating submissions to have rating agencies analyze amortization schedules less onerous on issuers than full turbo structures ("full turbo" means that all cash flow after items of a higher priority in the waterfall provisions have been paid must be applied to reduce principal, rather than being available for release to Issuer).

\subsubsection{Collateral Pool Overview}

\subsubsection{Customer Profile and Contracts}

To portray the credit quality of the solar customers (or "off-takers") in the collateral pool, the SAPC deal team developed a $\mathrm{FICO}^{8}$ distribution for all SolarCo installations by state, date of installation, and other sources of differentiation. FICO distributions of SolarCo installations ranged from 700 to 770 and above with a weighted average of 765 (Figure 3 and Figure 4). Although the values and the portfolio are fictional, the distribution ranges were based on actual portfolio data from several SAPC members involved in residential solar finance and development.

\footnotetext{
${ }^{6}$ KBRA. (2015). Sunrun Callisto Issuer 2015-1, LLC, Series 2015-1.

${ }^{7}$ KBRA. (2015). SolarCity LMC Series IV, LLC, Series 2015-1.

${ }^{8}$ FICO score is the Fair Isaac Corporation method for rating the financial strength of consumers, and is one of the most common means of determining an individual's creditworthiness.
} 


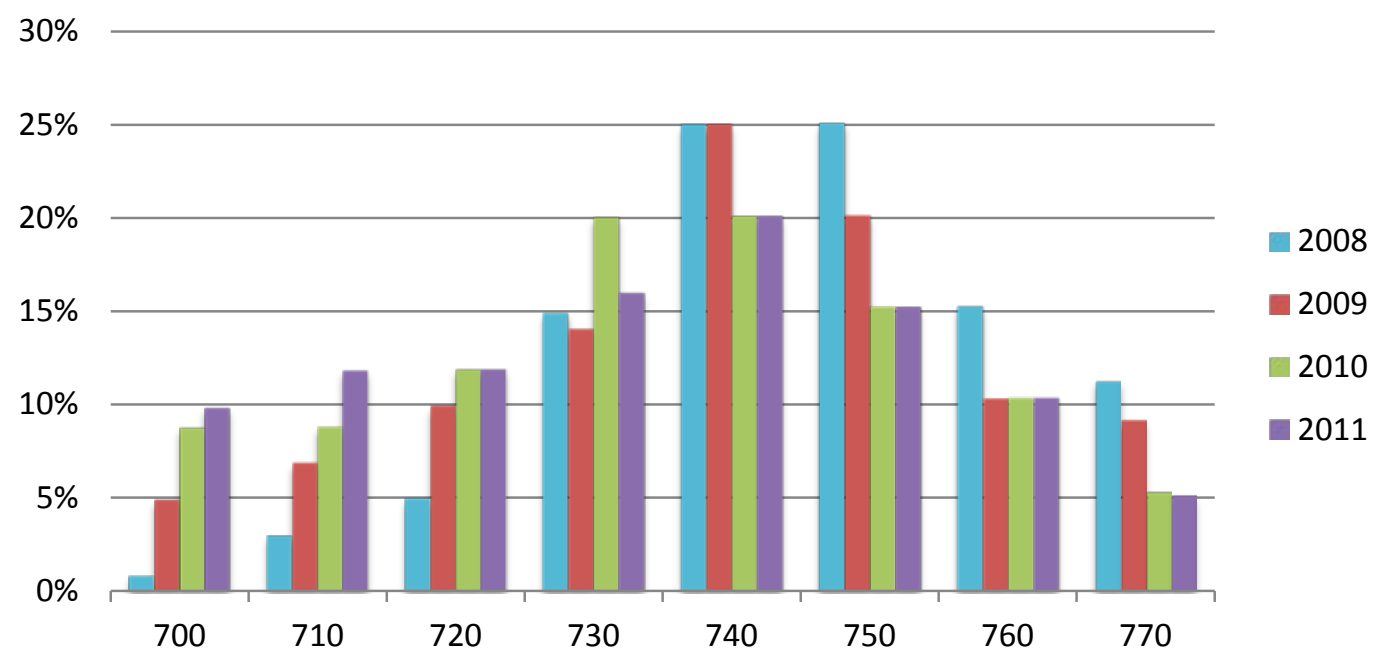

Figure 3. FICO score distribution by installation year

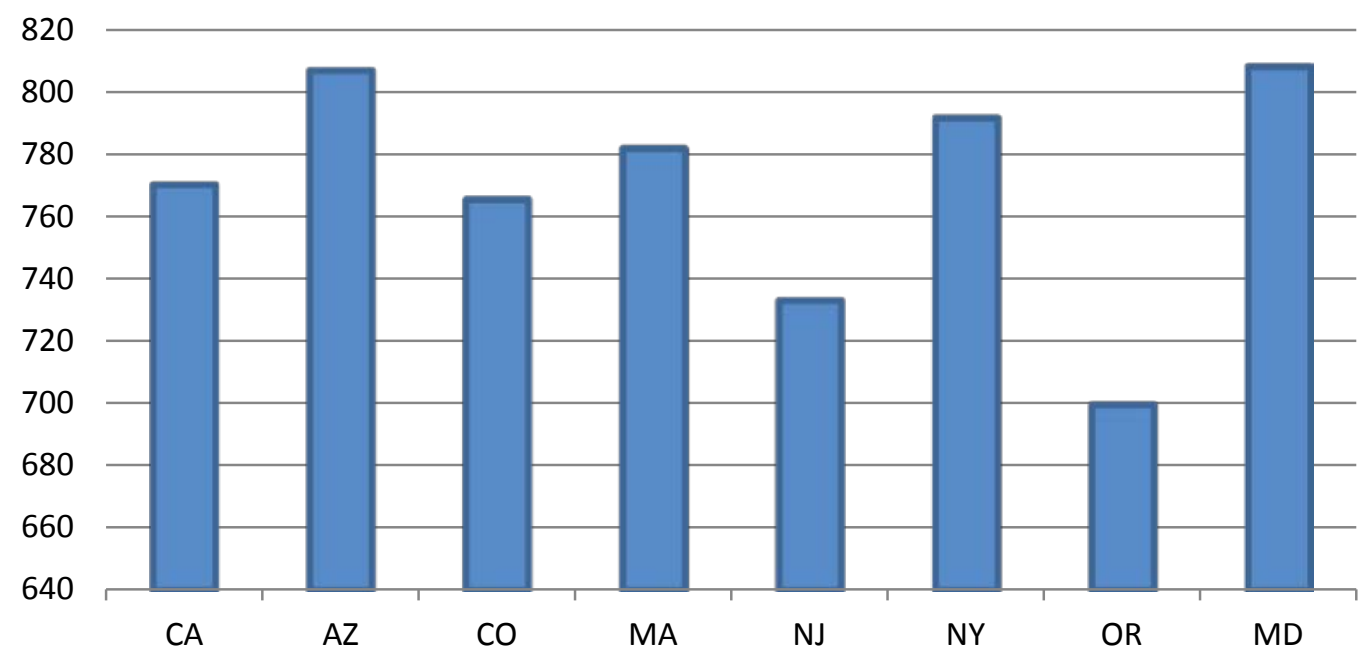

Figure 4. Average FICO score

Weighted average: 765

Similarly, contract defaults were based on actual payment-history data collected by SAPC members in the servicing business. Table 2 represents the information transferred to the rating agencies regarding the vintage of the asset, distribution of asset age, number of defaults, and service transfers with loss (i.e., to a collection agency). 
Table 2. Asset Performance Statistics

\begin{tabular}{|c|c|c|c|c|c|c|c|c|}
\hline \multirow[b]{2}{*}{$\begin{array}{l}\text { Placed In } \\
\text { Service } \\
\text { Vintage }\end{array}$} & \multirow[b]{2}{*}{$\begin{array}{l}\text { No. of } \\
\text { Systems } \\
\text { Placed in } \\
\text { Service }\end{array}$} & \multirow[b]{2}{*}{$\begin{array}{c}\text { Avg. } \\
\text { Contract } \\
\text { Age } \\
\text { (Months) }\end{array}$} & \multicolumn{2}{|c|}{$\begin{array}{l}\text { Service } \\
\text { Transfer } \\
\text { Cases }\end{array}$} & \multicolumn{2}{|c|}{$\begin{array}{c}\text { Service } \\
\text { Transfers } \\
\text { Resulting in } \\
\text { Default }\end{array}$} & \multicolumn{2}{|c|}{$\begin{array}{c}\text { Service } \\
\text { Transfers } \\
\text { Resulting in } \\
\text { Loss }\end{array}$} \\
\hline & & & No. & $\begin{array}{c}\% \text { of } \\
\text { Vintage }\end{array}$ & No. & $\begin{array}{c}\% \text { of } \\
\text { Vintage }\end{array}$ & No. & $\begin{array}{c}\% \text { of } \\
\text { Vintage }\end{array}$ \\
\hline 1H 2009 & 100 & 55 & 5 & 5.00 & 2 & 2.00 & - & $0.00 \%$ \\
\hline $2 \mathrm{H} 2009$ & 200 & 53 & 18 & 9.00 & 2 & 1.00 & - & $0.00 \%$ \\
\hline $1 \mathrm{H} 2010$ & 1,000 & 43 & 85 & 8.50 & 14 & 1.40 & 10 & $1.00 \%$ \\
\hline $2 \mathrm{H} 2010$ & 1,200 & 41 & 71 & 5.90 & 6 & 0.50 & 5 & $0.40 \%$ \\
\hline 1H 2011 & 1,500 & 31 & 90 & 6.00 & 29 & 1.90 & 6 & $0.40 \%$ \\
\hline 2H 2011 & 2,000 & 29 & 96 & 4.80 & 18 & 0.90 & 2 & $0.10 \%$ \\
\hline 1H 2012 & 2,500 & 19 & 85 & 3.40 & 10 & 0.40 & 10 & $0.40 \%$ \\
\hline 2H 2012 & 3,400 & 17 & 92 & 2.70 & 17 & 0.50 & 3 & $0.10 \%$ \\
\hline $1 \mathrm{H} 2013$ & 4,100 & 8.5 & 41 & 1.00 & 12 & 0.30 & - & $0.00 \%$ \\
\hline 2H 2013 & 4,000 & 2.5 & 4 & 0.10 & 0 & 0.01 & - & $0.00 \%$ \\
\hline Total & 20,000 & & & & & & & \\
\hline
\end{tabular}

\begin{tabular}{lcccc}
$\begin{array}{l}\text { Reason For } \\
\text { Transfer }\end{array}$ & $\begin{array}{c}\text { Original Contract Value } \\
\text { at Transfer }\end{array}$ & $\begin{array}{c}\text { Reassign } \\
\text { Contract Value }\end{array}$ & Recovery \\
Bankruptcy & 3 & 36,750 & 36,750 & $100.00 \%$ \\
Death of Assignor & 40 & 490,000 & 498,000 & $101.63 \%$ \\
Divorce & 20 & 245,000 & 242,000 & $98.78 \%$ \\
Foreclosure & 15 & 183,750 & 174,000 & $94.69 \%$ \\
Moving & 500 & $6,125,000$ & $6,200,000$ & $101.22 \%$ \\
Short-sale & 75 & 918,750 & 900,000 & $97.96 \%$ \\
Totals & $\mathbf{6 5 3}$ & $\mathbf{7 , 9 9 9 , 2 5 0}$ & $\mathbf{8 , 0 5 0 , 7 5 0}$ & $\mathbf{1 0 0 . 6 4 \%}$ \\
\hline
\end{tabular}

Another key statistic related to asset credit quality has to do with the economic value of the solar systems vis-à-vis utility-provided electricity. Rating agencies consistently indicated concern that the value proposition of solar leases and PPAs may decline over the life of the system because contract price escalators might raise a consumer's price for electricity above the utility rate. This would give a customer less incentive to uphold their contract and put them at risk of possible default or renegotiation. Other reasons for "economic obsolescence" of solar contracts include: (i) utility power cost decline due to significant reduction in fuel costs, and (ii) dramatic solarsystem price decline leading to customers replacing their systems and refusing to make payments on the original systems.

The mock deal team responded to these concerns with two primary arguments. First, natural gas prices, which represent a large and growing percentage of utility fuel costs, have been at historic lows over the past several years when solar installations have had their most dramatic increase. It was the opinion of the SAPC deal team that natural gas prices would not further decline and put downward pressure on utility rates, and even if that were to occur, recent data suggested that this would not adversely affect the growth of the distributed solar sector. Further, reliance on natural gas continues to grow due to its low environmental impact (i.e., mercury and carbon output) relative to coal. 
Second, although the cost per watt of solar installations has decreased dramatically since 2008, this has, until recently, been primarily due to downward pressure on the cost of modules. Today, the module costs represent a smaller portion of the overall cost of the installation (less than half by most estimates) and are falling at a lesser rate relative to the dramatic reductions of the recent past. More prominent today are the balance-of-system costs—siting, permitting, financing, and others - which are falling but not as steeply as modules once did. Thus, it was the opinion of the SAPC deal team that system costs, although still on the decline, are not likely to see the kinds of reductions in the near to mid term that would justify a contract renegotiation. Importantly, among SAPC members in residential solar development and finance, there was not a single reported case of a solar customer replacing and refusing to make a payment on an existing system.

The deal team also pointed out that the utility bill is a relatively minor portion of a residential homeowner's monthly budget. Thus, it is expected that a homeowner will have limited economic motivation to attempt to change to a new solar panel system or to terminate the lease or PPA for any other reason.

\subsubsection{Assets}

In addition to the credit history of the off-takers, the SolarCo portfolio mirrored industry inventory in several other important aspects, including average system size $\left(6.84 \mathrm{~kW}_{\mathrm{DC}}\right)$, original term (240 months), and geographic distribution (61.2\% of assets in California and $10.1 \%$ in Arizona). Table 3 (next page) summarizes the asset performance characteristics of the simulated portfolio.

The SolarCo transaction securitized a portfolio of 7,200 residential lease agreements, which were selected to represent a large, vertically integrated developer's current inventory. These contracts were valued by a common metric: the average discounted solar contract balance (ADSCB), the remaining amount due by each off-taker in the portfolio discounted over the remaining period of the contract, and then summed with the rest of the portfolio. The discount rate was assumed to correspond to the borrowing rate of the issuer, which is $6.5 \%$. Payments made by a government agency as part of any solar energy incentive programs were initially retained by SolarCo and were not part of this securitization.

The securitization was sized to raise $\$ 100$ million in an asset-backed facility by selling securities to qualified institutional buyers (QIBs) under SEC Rule 144A. The sale of the securities was arranged and managed by Global Investment Bank, a fictional bond-underwriting firm. The security structure was tranched into two segments: tranche A, representing $40 \%$ of the total bonds issued, and having a senior claim on the underlying cash flows; and tranche $\mathrm{B}$, representing $60 \%$ of the total bonds issued, and having a subordinated claim on the underlying cash flows. 
Table 3. Asset Performance Characteristics

\begin{tabular}{|c|c|c|c|c|c|c|c|c|c|}
\hline $\begin{array}{l}\text { Geographic } \\
\text { Distribution }\end{array}$ & $\begin{array}{l}\text { Number } \\
\text { of PV } \\
\text { Systems }\end{array}$ & $\begin{array}{l}\text { Percentage } \\
\text { of Total PV } \\
\text { Systems } \\
\text { (\%) }\end{array}$ & ADSCB (\$) & $\begin{array}{l}\text { Percentage } \\
\text { of ADSCB } \\
\text { (\%) }\end{array}$ & $\begin{array}{l}\text { Weighted } \\
\text { Average } \\
\text { PV } \\
\text { System } \\
\text { Size } \\
\left(\text { kW }_{\text {DC }}\right)\end{array}$ & $\begin{array}{l}\text { Weighted } \\
\text { Average } \\
\text { Off-Taker } \\
\text { Electric } \\
\text { Savings vs. } \\
\text { Utility (\%) }\end{array}$ & $\begin{array}{l}\text { Weighted } \\
\text { Average } \\
\text { Escalator } \\
\text { Rates (\%) }\end{array}$ & $\begin{array}{l}\text { Weighted } \\
\text { Average } \\
\text { Price per } \\
\text { kWh (\$) }\end{array}$ & $\begin{array}{l}\text { Weighted } \\
\text { Average } \\
\text { FICO }\end{array}$ \\
\hline California & 3,665 & 50.9 & $62,967,828$ & 61.2 & 6.80 & 15.9 & 1.5 & 0.1684 & 768 \\
\hline Arizona & 911 & 12.7 & $10,402,378$ & 10.1 & 6.78 & 16.2 & 1.5 & 0.0991 & 767 \\
\hline New Jersey & 365 & 5.1 & $4,678,006$ & 4.5 & 6.91 & 15.6 & 1.6 & 0.1544 & 769 \\
\hline Hawaii & 180 & 2.5 & $4,478,459$ & 4.4 & 7.09 & 14.7 & 1.3 & 0.2271 & 770 \\
\hline New York & 469 & 6.5 & $4,303,219$ & 4.2 & 6.76 & 15.5 & 1.5 & 0.1365 & 767 \\
\hline Colorado & 449 & 6.2 & $4,111,963$ & 4.0 & 6.91 & 15.7 & 1.6 & 0.0936 & 772 \\
\hline Massachusetts & 393 & 5.5 & $3,378,545$ & 3.3 & 6.84 & 16.1 & 1.5 & 0.1236 & 771 \\
\hline Connecticut & 185 & 2.6 & $2,204,874$ & 2.1 & 7.10 & 15.8 & 1.5 & 0.1418 & 770 \\
\hline Maryland & 246 & 3.4 & $2,075,483$ & 2.0 & 6.87 & 15.2 & 1.7 & 0.0980 & 771 \\
\hline Oregon & 124 & 1.7 & $1,602,296$ & 1.6 & 7.06 & 15.4 & 1.5 & 0.1366 & 766 \\
\hline Wyoming & 62 & 0.9 & 890,351 & 0.9 & 6.86 & 15.1 & 1.8 & 0.1529 & 767 \\
\hline Utah & 44 & 0.6 & 618,984 & 0.6 & 7.06 & 15.1 & 1.4 & 0.1529 & 775 \\
\hline Delaware & 40 & 0.6 & 451,093 & 0.4 & 7.24 & 14.6 & 2.0 & 0.1110 & 767 \\
\hline Washington, DC & 44 & 0.6 & 362,466 & 0.4 & 7.19 & 17.6 & 1.5 & 0.0988 & 769 \\
\hline Idaho & 23 & 0.3 & 309,557 & 0.3 & 6.77 & 19.2 & 1.5 & 0.1455 & 774 \\
\hline Total: & 7,200 & 100.0 & $102,835,502$ & 100.0 & 6.84 & 15.8 & 1.5 & 0.1543 & 769 \\
\hline
\end{tabular}




\subsubsection{Cash Flows and Scenario Analysis}

When evaluating a securitization transaction, rating agencies do not simply perform a static review of the underlying assets, but instead, they use those assets' characteristics to shape scenarios that stress the receivables' cash flows. The rating being sought also determines some of the inputs for these scenarios in order to project how likely bonds are to receive all required principal and interest payments on a timely basis. Among other data points, these inputs include:

- The rate at which borrowers prepay amounts due (either in part or in whole) before scheduled receipt;

- The rate at which borrowers default on contractual payments and the portion of a defaulted contract that can be recouped.

The rate of prepayment observable in SAPC data was relatively low and generally corresponded to the rate at which borrowers sold their homes. Unlike a residential mortgage, there is no opportunity to refinance a solar lease or PPA at a lower interest rate; therefore, there is little incentive to prepay. However, if a home is sold and the new owner does not assume the lease payments, full payment of all contracted amounts becomes due.

Given the preponderance of data on residential mortgages and the nature of prepayments, discussions with rating agencies focused on the rate at which borrowers could be expected to default. Unlike MBS and ABS generally, the process of delinquency and default often does not lead to the liquidation of the asset and the cessation of payments to the securitization trust after a final recovery. Repossessed panels have little commercial value, and thus, liquidation is an ineffective remedy for default. However, borrowers also have greater incentive to continue making payments if they live in their house (especially if the solar panels save money on electricity bills). In the event a home is foreclosed on and the original off-taker vacates, the bank taking over the property must keep the electricity on in order to maintain the property prior to resale; thus, the incentive to pay the panel lease continues. Therefore, solar contracts are more susceptible to payment interruptions of an indeterminate but finite period of time than to a final liquidation and recovery. This leads to a subset of questions unique to understanding losses under solar contracts:

- Why would off-takers cease making payments?

- What is the probability of off-takers ceasing to make payments? How many off-takers eventually resume payments?

- How long will it take for off-takers to resume payments?

- What percentage of the original bill is collected when off-takers resume payments (both in arrears and going forward)?

To answer these questions and address the risk factors unique to solar, SAPC worked with the accounting firm KPMG to build a solar cash-flow model for residential (and commercial) projects, allowing for the aggregation and "stressing" of variables that impact the timely receipt of payments from solar assets. The model, referred to by KPMG and the SAPC deal team as the SunCurve, reflected the probability of interruption to or losses in cash flow, and it was developed using data provided by SAPC solar developers, independent engineers, and other industry participants. It incorporates eight unique components that may result in losses to expected cash 
flows, including but not limited to delinquencies, renegotiations, bankruptcies, system repossessions, and technological failures.

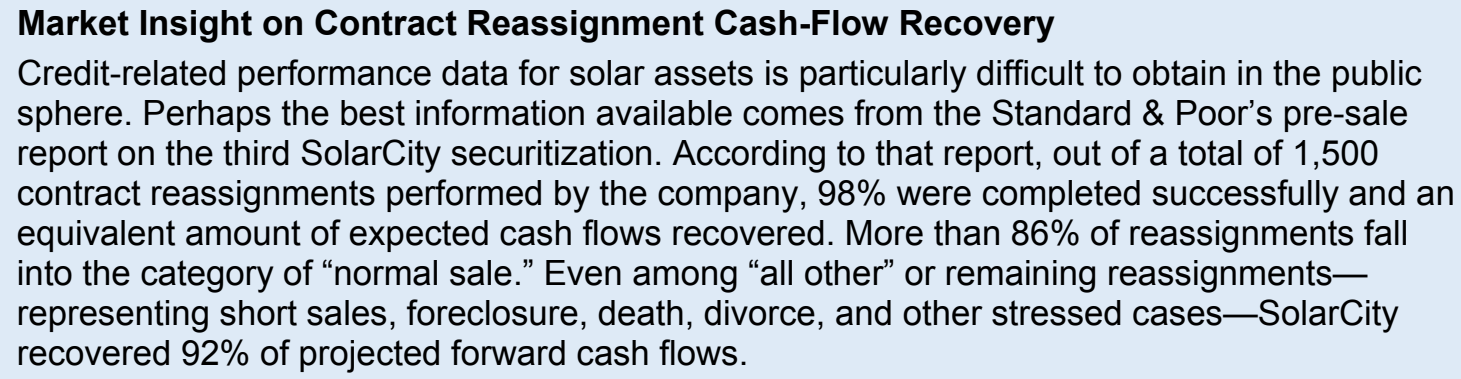
sphere. Perhaps the best information available comes from the Standard \& Poor's pre-sale report on the third SolarCity securitization. According to that report, out of a total of 1,500 contract reassignments performed by the company, $98 \%$ were completed successfully and an equivalent amount of expected cash flows recovered. More than $86 \%$ of reassignments fall into the category of "normal sale." Even among "all other" or remaining reassignmentsrepresenting short sales, foreclosure, death, divorce, and other stressed cases-SolarCity recovered $92 \%$ of projected forward cash flows.

The following tables are reprints from the S\&P presale report for SolarCity's Series III issuance.*

\begin{tabular}{|l|c|c|c|}
\hline $\begin{array}{c}\text { Reason for Contract } \\
\text { Reassignment }\end{array}$ & $\begin{array}{c}\text { \% of Completed } \\
\text { Contract } \\
\text { Reassignments }\end{array}$ & $\begin{array}{c}\text { Completed Contract } \\
\text { Reassignment as a \% } \\
\text { of Total PV Systems }\end{array}$ & Recovery (\%) \\
\hline Normal Sale & 86.5 & 1.9 & 99 \\
\hline All other & 13.5 & 0.3 & 92 \\
\hline Total & 100.0 & 2.2 & 98 \\
\hline
\end{tabular}

\begin{tabular}{|l|c|c|}
\hline \multicolumn{1}{|c|}{$\begin{array}{c}\text { Result of } \\
\text { Reassignment }\end{array}$} & $\begin{array}{c}\text { \% of Completed } \\
\text { Contract } \\
\text { Reassignments }\end{array}$ & Recovery (\%) \\
\hline Full recovery & 92 & 100 \\
\hline Less than full recovery & 8 & 82 \\
\hline Total & 100 & 98 \\
\hline
\end{tabular}

* S\&P (Standard and Poor's). 2014b. SolarCity LMC Series III LLC (Series 2014-2)

The SunCurve was based on the historical probability of portfolio default rates observed in SAPC data, which averaged about $0.6 \%$ with individual loss events averaging 2.3 months. Those values were increased over time to conservatively model the long-term risks of solar assets for which there is still little historical data. The result was that $0.85 \%$ of the original advance discounted solar contract balance ADSCB of the SolarCo portfolio was lost using the SunCurve's baseline assumptions. Different iterations were created and applied to the mock securitization to anticipate some of the more conservative scenarios that the rating agencies would apply related to additional losses, prepayments, and O\&M fees. Apart from those scenarios that ran multiples of the historical SunCurve, additional scenarios fell into two general categories:

- The first category was meant to simulate the effects of some extreme future event. For example, one scenario simulated another housing crisis that led to foreclosures on homes with solar systems at an annual rate of $40 \%$ for 18 months. Another scenario simulated a rapid increase in panel failures, to the point where one out of every three installed systems needed to be taken off-line for an extended period and repaired by the eighth 
year of the securitization. The last scenario was meant to simulate the evolution of a new technology that would disrupt the residential solar market and invert the value proposition of solar leases;

- The second category of scenarios took a top-down, or macro, approach. Because the long-term dynamics of solar portfolios are still unknown, the mock securitization process demonstrated to the rating agencies how the securitization would perform assuming certain levels of losses but without specifying the underlying causes of the losses. These assumptions spread out defaults equal to $2 \%, 4 \%, 8 \%$, and $10 \%$ of $\mathrm{ADSCB}$, front-loading losses at the beginning of the deal in some scenarios whereas back-loading losses at the end of the deal in others. Table 4 summarizes 14 different sets of collateral assumptions presented to rating agencies, as well as a $15^{\text {th }}$ scenario created from feedback solicited after each meeting.

Three particular scenarios were discussed at length during the meetings with the ratings agencies: the SunCurve 2x scenario, the Cumulative Loss 4.0\% Front-Loaded scenario, and the Technological Evolution scenario. These are presented in greater detail in Sections 2.2.4.1, 2.2.4.2, and 2.2.4.3, respectively. 
Table 4. Scenarios Presented to Rating Agencies

\begin{tabular}{|c|c|c|c|c|c|c|}
\hline & Scenario Name & $\begin{array}{l}\text { Prepay } \\
\text { Speed }\end{array}$ & $\begin{array}{l}\text { Payment } \\
\text { Delay }\end{array}$ & $\begin{array}{l}\text { Severity } \\
(\%)\end{array}$ & Description and Loss Probability & $\begin{array}{l}\% \text { of UPB* } \\
\text { Realized Loss }\end{array}$ \\
\hline 1 & $\begin{array}{l}0 \% \text { Prepay } 0 \% \\
\text { Default }\end{array}$ & $0 \%$ CPR & 0 & 0 & No losses & 0 \\
\hline 2 & SunCurve 1x & $1 \%$ CPR & 3 & 10 & $\begin{array}{l}\text { Historical probability of default, foreclosure, and } \\
\text { bankruptcy are projected for the first } 3 \text { years, then } \\
\text { the weighted average of the historical data (about } \\
0.6 \% \text { ) is increased } 5 \% \text { every two years until Year } 15\end{array}$ & 0.85 \\
\hline 3 & SunCurve $2 x$ & $2 \%$ CPR & 6 & 20 & $\begin{array}{l}\text { Double the historical probability of default, } \\
\text { foreclosure, and bankruptcy are projected for the } \\
\text { first } 3 \text { years, then the weighted average of the } \\
\text { historical data (about } 1.2 \% \text { ) is increased } 5 \% \text { every } \\
\text { two years until Year } 15\end{array}$ & 3.33 \\
\hline 4 & $\begin{array}{l}\text { Cum Loss } 2.0 \% \text { - } \\
\text { Front-Loaded }\end{array}$ & $1 \%$ CPR & 24 & 10 & $\begin{array}{l}\text { A total loss amount is calculated }(2 \%) \text {, then } 70 \% \text { is } \\
\text { applied within the first } 5 \text { years }\end{array}$ & 2.00 \\
\hline 5 & $\begin{array}{l}\text { Cum Loss } 2.0 \% \text { - } \\
\text { Back-Loaded }\end{array}$ & $1 \%$ CPR & 24 & 10 & $\begin{array}{l}\text { A total loss amount is calculated ( } 2 \%) \text {, then } 95 \% \text { is } \\
\text { applied after Year } 10\end{array}$ & 2.00 \\
\hline 6 & $\begin{array}{l}\text { Cum Loss } 4.0 \% \text { - } \\
\text { Front-Loaded }\end{array}$ & $1 \% \mathrm{CPR}$ & 24 & 10 & $\begin{array}{l}\text { A total loss amount is calculated ( } 4 \%) \text {, then } 70 \% \text { is } \\
\text { applied within the first } 5 \text { years }\end{array}$ & 4.00 \\
\hline 7 & $\begin{array}{l}\text { Cum Loss } 4.0 \% \text { - } \\
\text { Back-Loaded }\end{array}$ & $1 \%$ CPR & 24 & 10 & $\begin{array}{l}\text { A total loss amount is calculated ( } 4 \%) \text {, then } 95 \% \text { is } \\
\text { applied after Year } 10\end{array}$ & 4.00 \\
\hline 8 & $\begin{array}{l}\text { Cum Loss } 8.0 \% \text { - } \\
\text { Front-Loaded }\end{array}$ & $1 \%$ CPR & 12 & 10 & $\begin{array}{l}\text { A total loss amount is calculated }(8 \%) \text {, then } 70 \% \text { is } \\
\text { applied within the first } 5 \text { years }\end{array}$ & 8.00 \\
\hline 9 & $\begin{array}{l}\text { Cum Loss } 8.0 \% \text { - } \\
\text { Back-Loaded }\end{array}$ & $1 \%$ CPR & 24 & 10 & $\begin{array}{l}\text { A total loss amount is calculated ( } 8 \%) \text {, then } 95 \% \text { is } \\
\text { applied after Year } 10\end{array}$ & 8.00 \\
\hline 10 & $\begin{array}{l}\text { Cum Loss } 10.0 \% \text { - } \\
\text { Front-Loaded }\end{array}$ & $1 \%$ CPR & 12 & 10 & $\begin{array}{l}\text { A total loss amount is calculated }(10 \%) \text {, then } 70 \% \text { is } \\
\text { applied within the first } 5 \text { years }\end{array}$ & 10.00 \\
\hline
\end{tabular}




\begin{tabular}{|c|c|c|c|c|c|c|}
\hline & Scenario Name & $\begin{array}{l}\text { Prepay } \\
\text { Speed }\end{array}$ & $\begin{array}{l}\text { Payment } \\
\text { Delay }\end{array}$ & $\begin{array}{l}\text { Severity } \\
(\%)\end{array}$ & Description and Loss Probability & $\begin{array}{l}\% \text { of UPB* } \\
\text { Realized Loss }\end{array}$ \\
\hline 11 & $\begin{array}{l}\text { Cum Loss } 10.0 \% \text { - } \\
\text { Back-Loaded }\end{array}$ & $1 \%$ CPR & 24 & 10 & $\begin{array}{l}\text { A total loss amount is calculated (10\%), then } 95 \% \text { is } \\
\text { applied after Year } 10\end{array}$ & 10.00 \\
\hline 12 & $\begin{array}{l}\text { Housing Crisis } \\
\text { Simulation }\end{array}$ & $1 \% \mathrm{CPR}$ & 36 & 25 & $\begin{array}{l}1 \% \text { CDR until Year } 5 \text {, then } 1.5 \% \text { CDR in Year } 6 \text {, } \\
40 \% \text { CDR for the next } 18 \text { months and } 6 \% \text { CDR } \\
\text { thereafter }\end{array}$ & 14.50 \\
\hline 13 & $\begin{array}{l}\text { Panel Failure } \\
\text { Simulation }\end{array}$ & $1 \%$ CPR & 6 & 33 & $\begin{array}{l}\text { A very low CDR in Year 1, ramping up to } 30 \% \text { CDR } \\
\text { in Year } 8 \text { and falling to about } 20 \% \text { CDR after Year } \\
12\end{array}$ & 31.72 \\
\hline 14 & $\begin{array}{l}\text { Technological } \\
\text { Evolution } \\
\text { Simulation }\end{array}$ & $1 \% \mathrm{CPR}$ & 0 & 100 & $\begin{array}{l}\text { A very low CDR in Year 1, growing slowly until Year } \\
5 \text {, then ramping up to } 12.5 \% \text { CDR in Year } 7 \text { and } \\
\text { dropping thereafter }\end{array}$ & 30.59 \\
\hline 15 & $\begin{array}{l}\text { SAPC Mock } \\
\text { Feedback }\end{array}$ & $\begin{array}{l}1.7 \% \\
\text { CPR }\end{array}$ & 24 & 20 & $3 \%$ CDR & 3.73 \\
\hline
\end{tabular}




\subsubsection{SunCurve $2 x$}

The SunCurve $2 \mathrm{x}$ scenario was rooted in the historical data provided by SAPC members, but the inputs ${ }^{9}$ were deliberately increased by $100 \%$ at every level to illustrate a high-stress scenario. The result was losses equal to $3.33 \%$ of ADSCB over the life of the securitization.

Figure 5a and Figure 5b illustrate the cash flows to the tranches of the securitization and the two reserve accounts under the SunCurve 2x scenario. Figure 5a shows the balance of tranche A in blue and tranche B in red, as well as total asset cash flows at the top of the waterfall in green. Tranche A is fully paid down in the $135^{\text {th }}$ month, at which time-because principal allocation is sequential - principal payments start on tranche B. In this scenario, the average lives of tranches $\mathrm{A}$ and $\mathrm{B}$ are 6.0 and 13.7 years, respectively.

Figure $5 \mathrm{~b}$ shows the balance of liquidity and O\&M reserves in red and green, respectively, as well as the residual cash flow in blue. Because the liquidity reserve is proportional to future interest payments on tranches $\mathrm{A}$ and $\mathrm{B}$, and the balance of those tranches decreases monotonically, so too does the reserve. The O\&M reserve is unfunded for the first nine months because it is unlikely that any inverter replacements will be required during that period. After the nine-month grace period, the O\&M reserve builds up at a continuous rate to reach about \$9M. The peak of inverter replacements is projected to occur around the $100^{\text {th }}$ month, after which there is a sharp decrease in the reserve's balance as more systems in the portfolio require inverter replacements. After all inverters have been replaced once, around the $130^{\text {th }}$ month, the reserve keeps its floor of $\$ 20 /$ pool $\mathrm{kW}$. That floor is maintained to fund a potential second round of inverter replacements.

Figure $5 \mathrm{~b}$ also shows residual payments over the life of the deal, which occur each month at a level of around $\$ 50 \mathrm{~K}$ and then increase to $\$ 550 \mathrm{~K}$ per month after tranche B is fully paid down (around Month 190).
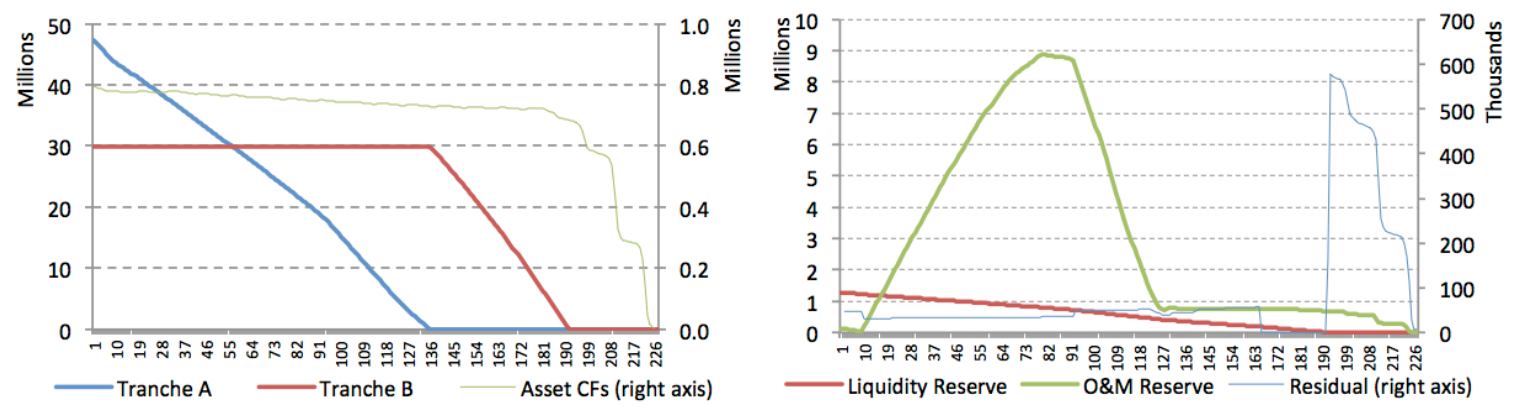

Figure 5. (a) SunCurve $2 x$ scenario cash flows; (b) SunCurve $2 x$ scenario residual payments

\subsubsection{4\% Cumulative Loss Front-Loaded}

The 4\% Cumulative Loss Front-Loaded scenario was presented as a universal benchmark for comparing asset classes. The scenario explores the effect of $4 \%$ total portfolio losses with $70 \%$ of those losses occurring within the first five years of the securitization issuance. The aggregate

9 These inputs included: probability of a loss event; length of a loss event; severity of a loss event; and probability of a prepayment. 
amount of losses - $4.00 \%$ - from this scenario represented a small increase over the SunCurve $2 x$ 's $3.33 \%$.

The timing of these losses has implications for the bond's payments. One can observe the dip in asset cash flows (Figure 6a) that occurs between Month 1 and Month 130 and the consequence on the maturity timing of tranches $\mathrm{A}$ and $\mathrm{B}$, which are both delayed by about 20 months. Their average lives become 7.2 and 15.3 years, respectively. The residual payments (Figure 6b) are also affected. Namely, the large payout in Month 190 in the SunCurve 2x scenario does not occur in the 4\% Cumulative Loss scenario.
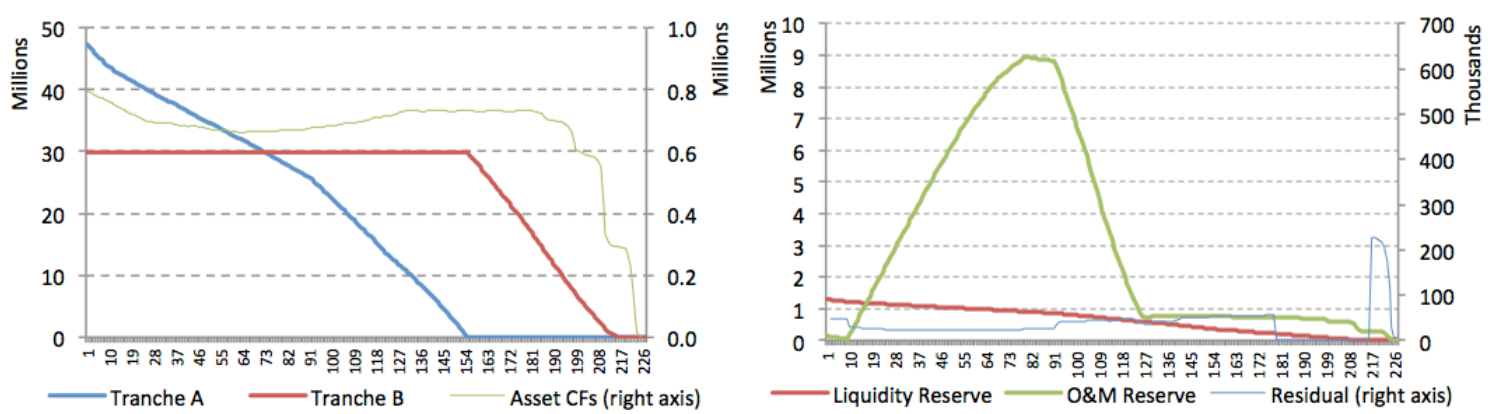

Figure 6. (a) Cumulative Loss Front-Loaded scenario cash flows; (b) $4 \%$ Cumulative Loss FrontLoaded scenario residual payments

\subsubsection{Technological Evolution}

The Technological Evolution scenario projects how the securitization would perform if a new technology were developed that would make the securitization's underlying solar systems technologically obsolete. Loss severity on systems in this scenario were assumed to be $100 \%$, as off-takers abandon old systems for newer technologies.

The Technological Evolution scenario was the most severe scenario presented by SAPC, although the Class A bond still amortized fully and received all principal (Figure 7a). Tranche B, however, does not fully pay down because of a sharp and permanent decrease in asset cash flows. Interestingly in this scenario, the average life of tranche A goes down to 6.3 years because losses on the asset side free up cash held in the O\&M reserve (Figure $7 b$ ) and accelerate amortization.
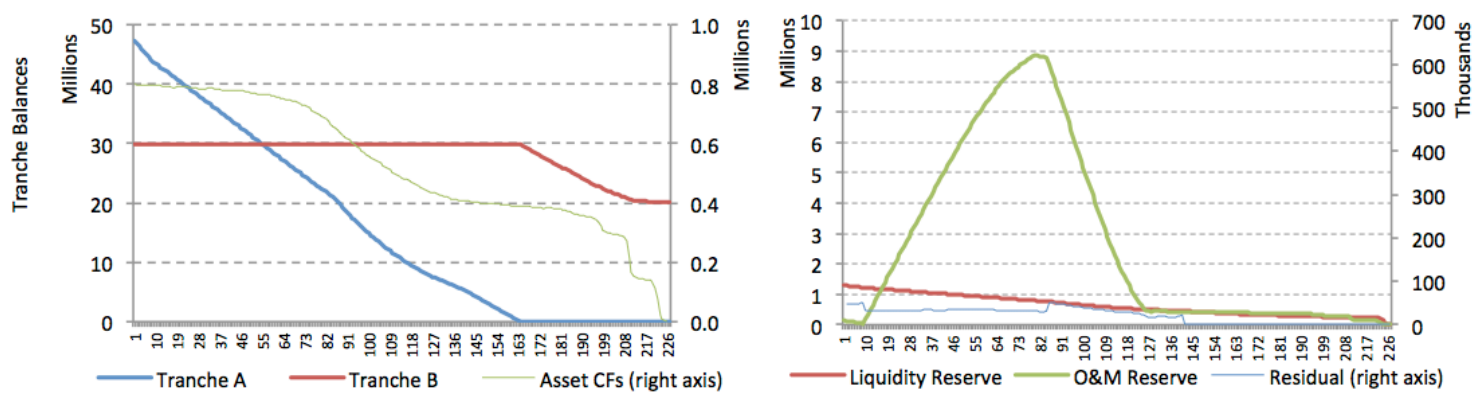

Figure 7. (a) The Technological Evolution scenario cash flows; (b) Technological Evolution scenario residual payments 


\subsection{Bond Structure and Notes}

The outputs of these scenarios - the collateral cash flows coming off of the underlying solar systems - must still be fed through the securitization's liability structure to see how the bonds will be paid over time. Modeling on the bond side is based on and tied into the collateral cash flows and projects cash distribution according to the securitization's priority of payments "waterfall." For the mock residential securitization, the waterfall consisted of 17 different steps (Figure 8).

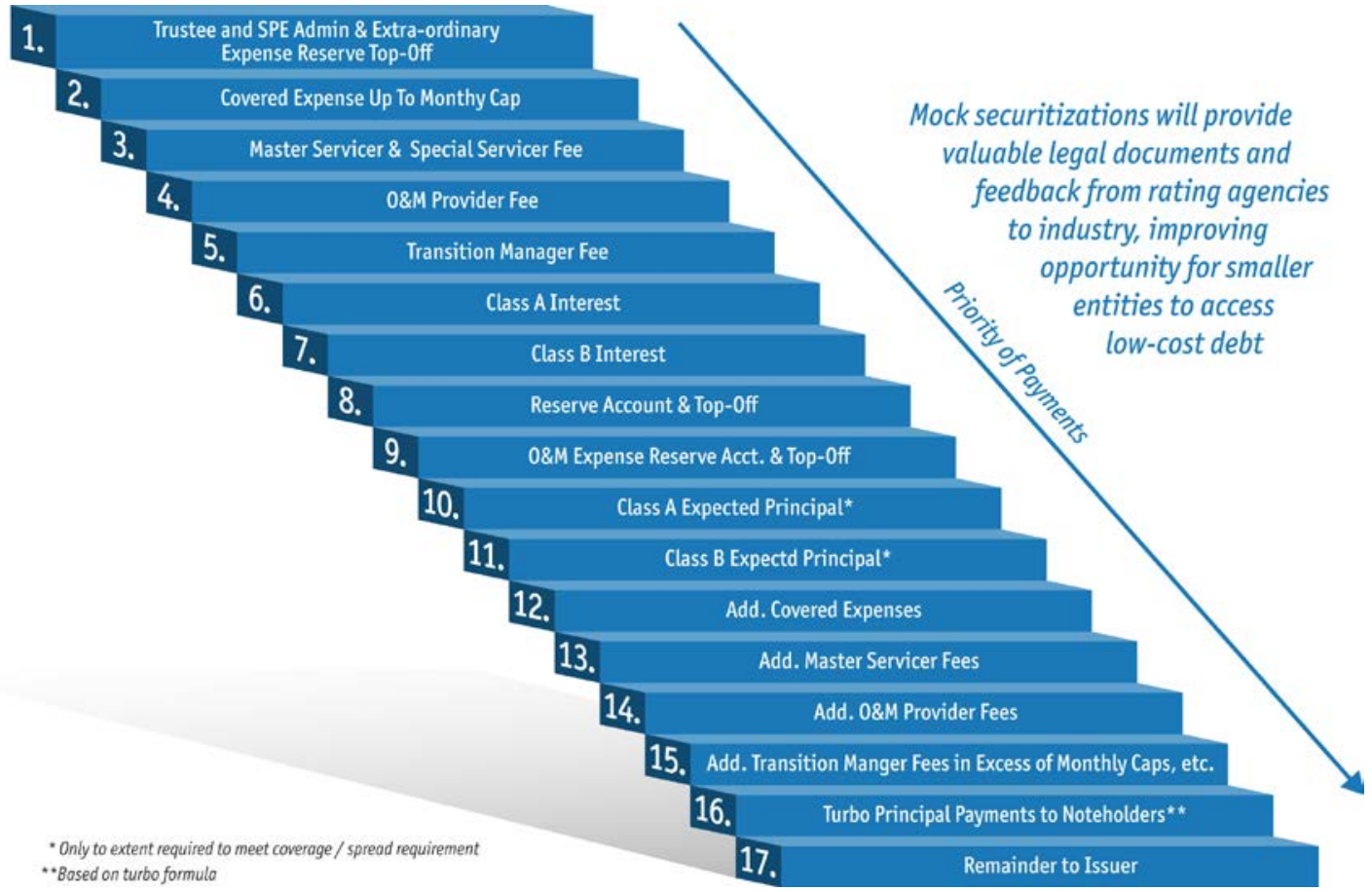

Figure 8. Residential securitization payment waterfall

The purpose of the structuring exercise was to find the appropriate level of overcollateralization, relative sizes of tranches $\mathrm{A}$ and $\mathrm{B}$, as well as target amount and funding rates of the O\&M reserve. The exercise consisted of striking a balance between efficiency and robustness of the structure. Choosing an excessive overcollateralization, for instance, might make the bonds more resistant to stresses but also reduces the portion of the capital stack raised at low interest rates (the A tranche). Building an excessively large O\&M reserve covers unexpected inverter failures but might also trap cash in the deal that could otherwise be used to pay down principal and/or be distributed earlier to the Issuer. This analysis was performed for each collateral scenario, and the results of the three previously highlighted scenarios are presented below.

The characteristics of the notes (i.e., securities) that would hypothetically be issued against the portfolio of residential assets are detailed in Table 5. 
Table 5. Residential Notes Characteristics

\begin{tabular}{|ll}
\hline Note Issuance Amount & $\$ 71,984,851$ \\
\hline ADSCB & $\$ 102,835,502$ \\
\hline Note Structure & Fixed-rate, two tranche senior/subordinate sequential pay \\
\hline Index & iSwaps \\
\hline SEC Exemption & $144 \mathrm{~A}$ \\
\hline Senior Note Spread & 100 basis points \\
\hline Junior Note Spread & 250 bps \\
\hline Overcollateralization & $30 \%$ \\
\hline Subordination & $60 \%$ \\
\hline DSCR* Sr. Notes & $1.40 x$ or greater \\
\hline DSCR Jr. Notes & $1.25 x$ or greater \\
\hline Liquidity Reserve Sr. & 9 months \\
\hline Liquidity Reserve Jr. & 3 months \\
\hline Target Avg. Life Sr. & 3 years \\
\hline Target Avg. Life Jr. & 7 years \\
\hline Target Final Maturity & May 2027 \\
\hline Use of Proceeds & Purchase tax-equity interest in InvestCo at flip date \\
\hline Assumed Credit Rating Sr. & AA \\
\hline Assumed Credit Rating Jr. & BBB+ \\
\hline *Debt Service Coverage Requirement \\
\hline
\end{tabular}




\section{C\&I Mock Portfolio and Process}

\subsection{Background}

The C\&I mock securitization was designed to show how a developer could use securitization as a source of capital to finance a pool of commercial rooftop solar systems. This is in distinction to the residential mock securitization, in which the capital raised through the transaction was intended to fund the developer's purchase of the solar assets after the tax equity's recapture period elapses (i.e., after the fifth year of the investment). Therefore, the C\&I mock differed from the residential mock not only because it was based on a portfolio of larger-scale assets with corporate off-takers, but also, because it developed a legal structure that would allow for the embedding of tax equity in the existing capital structure.

As mentioned in the introduction, tax-equity investors have historically resisted the pledging of renewable energy assets to a securitization vehicle because of the recapture risk it posed. To address this barrier, a legal working group within SAPC conceived of a structure whereby the tax-equity investor would be insulated in the case that an indenture trustee exercised its foreclosure rights if the issuer defaulted on its contractual obligations. This structure was premised on the inverted lease or lease pass-through structure - one of the three forms of taxequity financing in the renewable energy space. ${ }^{10}$ Under this structure, rather than having tax equity invest in the same partnership that owns the solar assets and the PPAs (as it would in a partnership flip), two separate entities are created - a lessor entity and a lessee entity - with the lessor entity owning the solar assets and leasing them to the lessee entity. The tax equity invests in the lessee entity only and the lessor elects under a special provision of the Internal Revenue Code to pass the $30 \%$ tax credit through to the lessee. Through this pass-through election, the tax equity receives the investment tax credit (but not the accelerated depreciation benefits), and in consideration for that and for a revenue stream, ${ }^{11}$ the tax equity invests capital into the lessee entity. This capital is then injected into the lessor entity in the form of prepaid rent. Although a portion of the rent obligation over the lease term is prepaid through this injection, the remaining installments are paid from PPA revenues.

At the time of the securitization, the lessor will assign all of its interests in the solar assets (including its rights as lessor under the lease) to the special purpose vehicle (SPV) issuer of the securitization notes, a wholly owned subsidiary of the lessor entity. Thus, the assets being securitized are the lessor's interests in the solar assets and the lease payments under the lease obligation (which are, in turn, being funded from PPA payments).

This variant of the inverted lease structure (referred to by the SAPC working group as the "Tandem Tax Equity-Securitization Structure") is intended to achieve the following results: (i) avoid having the tax equity and the developer-sponsor invest in the same entity, and thus remove the control of tax equity over decisions of the lessor, which in turn owns the issuer; and (ii) avoid the risk of recapture resulting from the pledge and potential foreclosure of the solar assets,

\footnotetext{
${ }^{10}$ The other two financing structures are partnership flips and sale leasebacks.

${ }^{11}$ This revenue stream represents the excess of the PPA revenues over the fixed rent required to be paid under the lease, and calculated to give the tax-equity investor a cash return to supplement the investment tax credit, thus giving the tax equity an after-tax market internal rate of return (IRR).
} 
because there will be no recapture for tax equity as long as the lease remains in force. Any entity buying the pledged assets in a foreclosure sale will be obligated to take title to the collateral subject to the lease as long as the lessee is still performing its obligations under the lease.

The C\&I mock also envisioned that the developer would take out a short-term, "warehouse" loan to finance part of the cost of designing, installing, and placing in service a pool of commercial rooftop solar systems. Most developers do not have access to long-term debt to refinance shortterm borrowing. As a result, most developers rely on equity-both tax equity and long-term cash equity - as a source of long-term project financing and as a source of funding repayment of the warehouse debt. Securitization offers a source of long-term - and importantly, low-costfinancing that could be used to replace all or portions of costlier equity capital. The securitization proceeds are applied to "take out" or refinance short-term loans; and by adding this leverage, the overall cost of project financing is lowered. Another advantage of securitization debt is that it is non-recourse to the developer, because the sole source of payment to the securitization investors comes from the cash flow generated from customers making their PPA payments.

Note that the complexities of the legal structure made the task of cash-flow modeling difficult. Accordingly, Section 3 does not display the same level of granularity in cash-flow analytics as does the residential mock deal. The C\&I mock filing was highly useful in reviewing the innovative legal structure alternative with the ratings agencies, although it does not necessarily offer as robust a portrait of how various stresses could affect repayment of the notes.

\subsection{Elements of the Commercial Mock Deal}

\subsubsection{Transaction Participants}

\section{The Developer: SolarCo/Sponsor/Manager}

The developer (SolarCo) for the commercial solar "mock" transaction is a corporation engaged in the development, management, and operation of solar-energy generating systems. It is responsible for overseeing the acquisition and/or design, site access, host contracting, and construction for each solar system and arranges for the construction, bridge, and term financing for the systems. As a manager, SolarCo manages under a management agreement the pool of assets being securitized and also either SolarCo or a third-party subcontractor performs O\&M functions under an operations \& maintenance agreement. Thus, SolarCo will provide directly or contract with a third-party to perform other services such as bill and collect payments from PPA agreements, monitor performance of the solar systems, monitor the O\&M services, pursue warranty claims against manufacturers, and prepare reports for investors.

The hypothetical developer for the commercial mock securitization operates under a "hybrid" (or disaggregated) business model, meaning that it performs directly some of the customer acquisition, system design and installation, system O\&M, and customer PPA billing and payment services in-house, but not all of these activities. Unlike a vertically integrated developer, which performs all stages of the development, installation, and management processes with employees, the hybrid developer may outsource customer acquisition and installation, but retain customer billing and payment processing. Others may outsource installation, operation, and maintenance, but perform all other activities. Hybrid developers usually focus on what optimizes their capability and profitability by contracting with third-party providers and hiring staff for key activities. 
These developers, including SolarCo, as stated above, have access to tax equity and can borrow short-term working capital (warehouse funding) to pay for initial installation costs and can negotiate tax-equity investment upon placing systems in service. However, they are often not able to obtain long-term debt to refinance or take out the short-term warehouse funding, but instead must use tax equity or strategic equity from another investor to pay off the short-term debt. This inability to leverage the cost of originating systems with long-term, low-cost debt significantly increases their funding costs.

It was the objective of the commercial mock securitization project to explore ways to help the hybrid developer in particular, as well as the vertically integrated developer, to obtain access to long-term debt while at the same time, as stated above, address friction points between tax-equity investors and securitization structures.

\section{The Securitization Issuer}

The issuer is a newly formed Delaware LLC organized for the sole purpose of owning the solar systems and the other interests of the lessor under the lease. The issuer is, as in the residential mock securitization submission, organized as a bankruptcy-remote special purpose entity to protect the collateral for the securitization from bankruptcy risk. Additionally, the lessee and the lessor are also organized as bankruptcy-remote special purpose entities. The cash flows under the PPAs are paid directly into a lockbox held by an institutional trustee, as the cash management agent, and the cash management agent will be instructed under the lockbox agreement to pay directly from the PPA cash flows to the securitization trustee the rent due each payment period under the lease, to pay certain expenses, and to pay to the lessee the remaining cash flow as the cash return on the tax equity's investment. The proceeds from the securitization notes will represent about $60 \%$ of the total financing for the projects. Tax equity and developer or strategic equity will provide the remaining $40 \%$.

\section{Project Co. and Tenant Co.}

The lessor ("Project Co") and the lessee ("Tenant Co") are, as stated above, limited-liability, special-purpose, bankruptcy-remote entities that are established specifically for the securitization structure.

\section{Back-Up or Sub-O\&M Provider and Servicer}

The C\&I mock securitization structure assumed, as stated above, that SolarCo may subcontract out O\&M services or customer billing and payment processing, and they would be named and their responsibilities and fees described in the transaction documents. Alternatively, if SolarCo performed either of these services, the securitization transaction structure assumes the possibility of SolarCo becoming unable to fulfill the responsibilities of these roles and the duties would be assigned to a "back-up" manager or "back-up" O\&M provider. A transition manager would determine any change in these roles, in consultation with the noteholder representatives.

\section{Transition Manager}

The transition manager is a national bank or other creditworthy institution that is appointed at the time the securitization notes are sold. They are responsible for monitoring the performance of the manager and O\&M provider, making recommendations about the need to transition all or a 
portion of those services to back-up or alternate service providers, and preparing a transition plan and obtaining any necessary approvals.

\section{Indenture Trustee}

The indenture trustee is the custodian and paying agent for the securitization note holders. It will also be an institutional trustee and will perform its duties under a trust indenture, under which the collateral for the securitization is pledged, the various accounts and reserves are established, the payment priority (also known as "waterfall") provisions are specified, events of default and trapping events and remedies therefor are established, and other directions and provisions relative to the notes and collection of funds to pay the notes are specified.

\subsubsection{Portfolio and Structure}

Rather than create a hypothetical portfolio and data tape as was used in the residential mock, the SACP C\&I mock team appropriated data on a pool of commercial rooftop solar projects and PPAs from an experienced renewable energy investor and member of the SAPC working group. Adapting real data in a "mock" securitization simplified the structuring exercise by reducing the amount of information that had to be derived based on a set of hypothetical assumptions. Additionally, it increased the credibility of the PPA cash-flow modeling and greatly improved the quality of the feedback from rating agencies and investors.

The data used were based on a pool of completed (in-service) rooftop commercial solar systems and PPA contracts and consisted of 19 commercial rooftop PV systems located in five northeastern states. They ranged in size from 47 to $1,500 \mathrm{~kW}_{\mathrm{DC}}$ and totaled 6.9 $\mathrm{MW}_{\mathrm{DC}}$. The systems were built with PV panels from seven different solar manufacturers and inverters were supplied by six different manufacturers.

All the systems were operational and had placed-in-service dates between 2010 and 2014. The systems were financed with PPAs with varying terms ranging from 15 years to 25 years. All but 1 of the 19 projects were financed with fixed-rate PPAs.

The expected cash flow from these systems was estimated on a net present value basis to be $\$ 24,088,730$ (assuming a 6\% discount rate). Figure 9 and Figure 10 offer a simplified version of the transaction diagram and a flow-of-funds diagram for the Tandem Tax Equity-Securitization

Structure, respectively. 


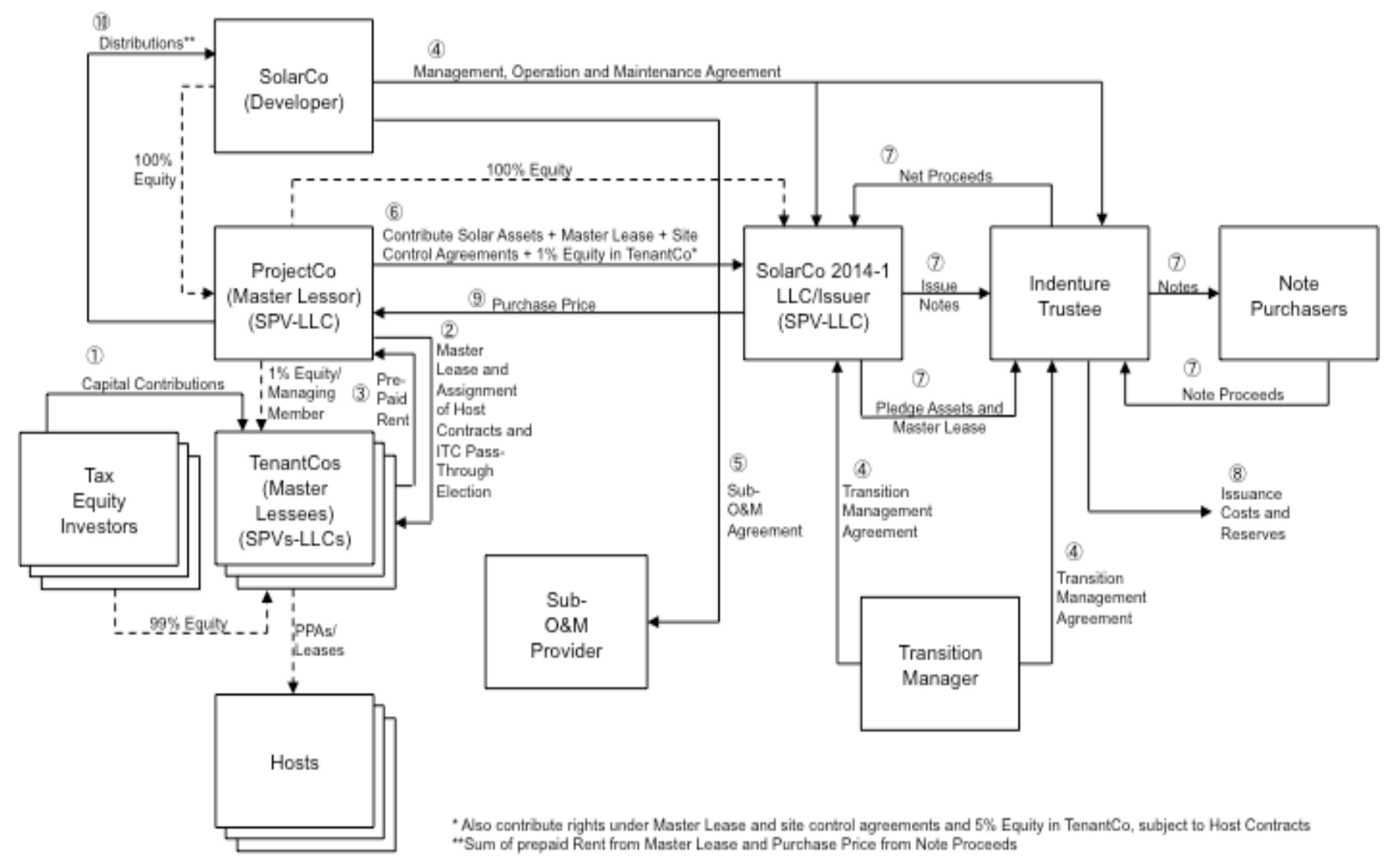

Figure 9. C\&I securitization legal structure transaction

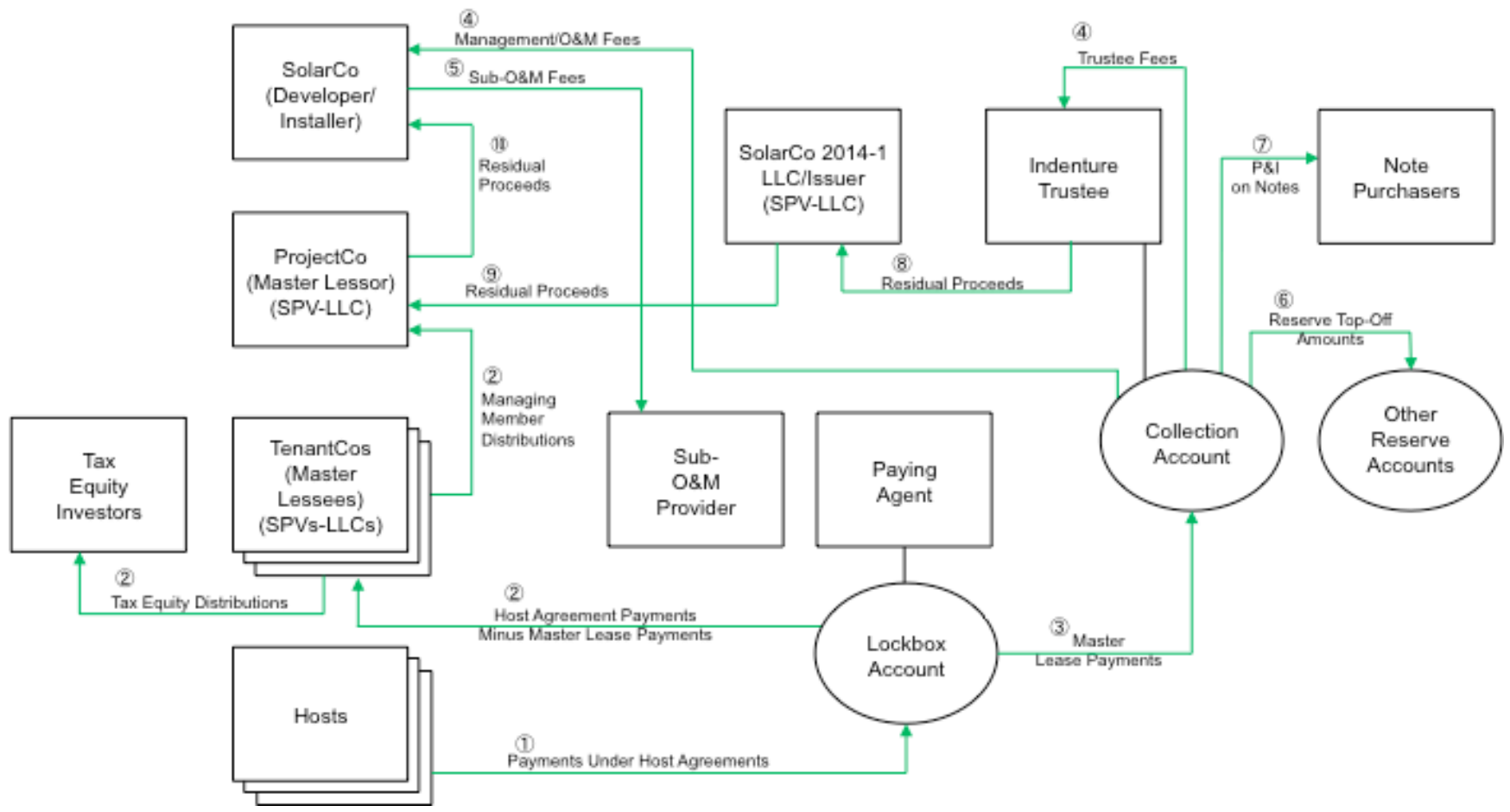

Figure 10. C\&I securitization flow of funds 
In the transaction waterfall (see Figure 11), all cash flow from PPA payments and other cash received from the projects is (as stated above) collected in a "lockbox" managed by the cash management agent (assumed to be the same institution as the Trustee). This cash is then disbursed based on a predetermined set of priorities specified in the lockbox agreement.

Unlike the residential mock securitization, only four default scenario cases were created for the C\&I structure rather than the extensive cash-flow scenario analysis and rating proxy methodology developed for the residential transaction. There were several reasons for this.

First, the primary focus of the C\&I mock proposal was to introduce the rating agencies to a new securitization legal structure and obtain their feedback. The legal structure was designed to reduce the risks to tax-equity investors when debt is introduced into the capital stack and make it easier for C\&I assets to be securitized. It was equally important that the structure not introduce any new risks or fail to address risks in the securitization structure that could adversely affect the securitization investors or the rating. Therefore, more time and resources were spent on refining and explaining the new structure to achieve these objectives.

Second, the size of the asset pool was relatively small and included only 19 projects. Typically, it would not be economical to securitize and obtain ratings on a pool this small. A larger pool could have been created by duplicating data to run a variety of stress-case scenarios. However, it was unclear if increasing the pool size by simply duplicating the data would generate meaningful results. Thus, it was decided to stay with the smaller pool size.

Finally, a key priority was validating the economics of the new structure by testing whether it would meet the return requirements of the sponsor, tax-equity investor, and securitization investors. Specifically, the C\&I mock structure assumes that the tax-equity investors inject their capital through an "inverted lease" structure, as opposed to the "partnership flip" structure assumed in the residential solar mock proposal. The actual pool data were based on projects already completed and cash-flowing for many months. Also, they were not originated in an inverted-lease structure. To validate the economics of the Tandem Tax Equity-Securitization Structure, significant analytical modeling was performed to reverse engineer the individual project cash flows to transform them into the required profile; i.e., projects that were recently placed in service using an inverted-lease structure and yielding market-based returns to the taxequity investor and the developer. Once the project cash flows were converted, it was possible to determine the size of the securitization that the cash flows could support, as well as to evaluate if the structure delivered the return objectives of all the deal participants.

\subsubsection{Collateral Pool Overview}

The following tables provide a summary of these characteristics. The same fictional company, SolarCo, was used in the C\&I mock as in the residential mock. Table 6 summarizes the pool characteristics. 
Table 6. Summary of Pool Characteristics

\begin{tabular}{ll}
\hline Pool Size & 19 PV systems totaling 6.97 MW \\
\hline Assets Placed in Service & $2010-2014$ \\
Asset Seasoning & 6 months -4.5 years \\
Location & $\mathrm{CT}, \mathrm{MA}, \mathrm{MD}, \mathrm{NJ}, \mathrm{RI}$ \\
Project Size Range & $47-1,500 \mathrm{~kW}$ DC \\
PPA Terms & $15-25$ years \\
PPA Rates & 18 fixed-rate; 1 variable $(2.5 \%$ escalator $)$ \\
Net Present Value of Cash Flows & $\$ 24,088,730(6 \%$ discount rate $)$ \\
Weighted Average Year-One Production & $517,518 \mathrm{kWh}$ \\
Weighted Average Price per kWh & $\$ 0.1770$ \\
\hline Tax Structure & Inverted lease \\
\hline
\end{tabular}

In Table 7, the project portfolio is delineated by project size. The SolarCo commercial portfolio has 19 projects ranging from less than $100 \mathrm{~kW}$ to over $1 \mathrm{MW}$ in size.

Table 7. SolarCo 2014-2 Project Size Stratification

\begin{tabular}{|llll}
\hline $\begin{array}{l}\text { Project Size } \\
(\mathbf{k W}\end{array}$ & $\begin{array}{l}\text { No. of } \\
\text { Projects }\end{array}$ & $\begin{array}{l}\text { Aggregate Project } \\
\text { Size }\left(\mathbf{k W}_{\text {DC }}\right)\end{array}$ & $\begin{array}{l}\text { \% of Aggregate } \\
\text { Project Size }\end{array}$ \\
\hline $\mathbf{1}$ to $\mathbf{1 0 0}$ & 2 & 91 & 1.31 \\
\hline $\mathbf{1 0 1}$ to $\mathbf{2 0 0}$ & 5 & 722 & 10.35 \\
\hline $\mathbf{2 0 1}$ to $\mathbf{3 0 0}$ & 4 & 949 & 13.62 \\
$\mathbf{3 0 1}$ to $\mathbf{4 0 0}$ & 1 & 344 & 4.93 \\
\hline $\mathbf{4 0 1}$ to $\mathbf{5 0 0}$ & 3 & 1,499 & 21.51 \\
\hline $\mathbf{5 0 1}$ to $\mathbf{6 0 0}$ & 1 & 516 & 7.40 \\
\hline $\mathbf{6 0 1}$ to $\mathbf{7 0 0}$ & 2 & 1,350 & 19.36 \\
\hline $\mathbf{2} \mathbf{1 , 0 0 1}$ & 1 & 1,500 & 21.52 \\
\hline Total & $\mathbf{1 9}$ & $\mathbf{6 , 9 7 1}$ & $\mathbf{1 0 0 . 0 0}$ \\
\hline
\end{tabular}

In Table 8, the SolarCo portfolio is stratified according to the starting price of power under the associated contracts (the contract prices may escalate at different rates) paid for by the off-taker. Just over $45 \%$ of the contracts sell solar power in the range of 6-10 cents per $\mathrm{kWh}$.

Table 8. SolarCo 2014-2 Starting Price for Delivered Power Stratification

\begin{tabular}{llll}
\hline $\begin{array}{l}\text { Off-Taker } \\
\text { Starting Rate } \\
\text { (\$/kWh) }\end{array}$ & $\begin{array}{l}\text { No. of } \\
\text { Projects }\end{array}$ & $\begin{array}{l}\text { Aggregate Project } \\
\text { Size }\left(\mathbf{k W}_{\mathbf{D C}}\right)\end{array}$ & $\begin{array}{l}\text { \% of Aggregate } \\
\text { Project Size }\end{array}$ \\
\hline $\mathbf{0 . 0 6}$ to $\mathbf{0 . 1 0}$ & 10 & 3,181 & 45.63 \\
$\mathbf{0 . 1 1}$ to $\mathbf{0 . 1 5}$ & 4 & 491 & 7.04 \\
\hline $\mathbf{0 . 2 1}$ to $\mathbf{0 . 2 5}$ & 1 & 1,500 & 21.52 \\
$\mathbf{0 . 3 1}$ to $\mathbf{0 . 3 5}$ & 4 & 1,799 & 25.81 \\
\hline Total & $\mathbf{1 9}$ & $\mathbf{6 , 9 7 1}$ & $\mathbf{1 0 0 . 0 0}$ \\
\hline
\end{tabular}


In Table 9, the SolarCo portfolio is stratified according to the location of the power plant. Geographic diversity is valuable in a portfolio in order to minimize regulatory risk to the performance of the securitization (i.e., change in any single state's law or regulations will not unduly impact the portfolio performance).

Table 9. SolarCo 2014-2 Project Portfolio Geographic Diversity

\begin{tabular}{llll}
\hline State & $\begin{array}{l}\text { No. of } \\
\text { Projects }\end{array}$ & $\begin{array}{l}\text { Aggregate Project } \\
\text { Size }\left(\mathbf{k W}_{\text {DC }}\right)\end{array}$ & $\begin{array}{l}\text { \% of Aggregate } \\
\text { Project Size }\end{array}$ \\
\hline RI & 4 & 2,800 & 40.17 \\
CT & 7 & 2,497 & 35.83 \\
NJ & 4 & 766 & 10.99 \\
MA & 2 & 736 & 10.56 \\
MD & 2 & 171 & 2.45 \\
Total & $\mathbf{1 9}$ & $\mathbf{6 , 9 7 1}$ & $\mathbf{1 0 0 . 0 0}$ \\
\hline
\end{tabular}

Table 10 describes the range of off-taker credit ratings, or the creditworthiness of the power purchasers under the portfolio. In the hypothetical SolarCo transaction, only 10 of the 19 projects in the portfolio have off-takers with an investment-grade credit rating. In reality, market concern over unrated or below-investment-grade off-takers (often smaller businesses that comprise the bulk of tenants in multi-tenant office and retail buildings) adds complexities to serving these enduse customers. This could hamper structured finance executions unless risk mitigants are identified.

Table 10. SolarCo 2014-2 Stratification of the Off-Taker Credit Rating

\begin{tabular}{llll}
\hline $\begin{array}{l}\text { Off-Taker } \\
\text { Credit Rating }\end{array}$ & $\begin{array}{l}\text { No. of } \\
\text { Projects }\end{array}$ & $\begin{array}{l}\text { Aggregate Project } \\
\text { Size }\left(\mathbf{k W}_{\text {DC }}\right)\end{array}$ & $\begin{array}{l}\text { \% of Aggregate } \\
\text { Project Size }\end{array}$ \\
\hline AA+ & 2 & 391 & 5.60 \\
A- & 2 & 843 & 12.09 \\
BBB & 1 & 237 & 3.40 \\
BBB+ & 4 & 2,800 & 40.17 \\
Unrated & 10 & 2,700 & 38.74 \\
Total & $\mathbf{1 9}$ & $\mathbf{6 , 9 7 1}$ & $\mathbf{1 0 0 . 0 0}$ \\
\hline
\end{tabular}

Table 11 describes the SolarCo portfolio by the duration of the solar renewable energy credit (SREC) contract. SRECs are specialized payments from electric utilities for the environmental benefits of solar energy. In several states, SREC contract durations and payments are fairly volatile. For that reason, SREC revenues are highly discounted or not directly considered when calculating the availability of funds to pay debt principal and interest for the securitized note. (Only where there is a stand-by purchaser of the issuer's SRECs with an investment-grade rating can full value for the cash flow associated with the SRECs be given in the securitization.) 
Table 11. SolarCo 2014-2 Duration of SREC Contracts

\begin{tabular}{llll}
\hline SREC Term & $\begin{array}{l}\text { No. of } \\
\text { Projects }\end{array}$ & $\begin{array}{l}\text { Aggregate Project } \\
\text { Size }\left(\mathbf{k W}_{\text {DC }}\right)\end{array}$ & $\begin{array}{l}\text { \% of Aggregate } \\
\text { Project Size }\end{array}$ \\
\hline $\mathbf{0}$ & 4 & 2,800 & 40.17 \\
$\mathbf{3}$ & 9 & 2,296 & 32.93 \\
$\mathbf{4}$ & 1 & 499 & 7.16 \\
$\mathbf{5}$ & 1 & 201 & 2.89 \\
$\mathbf{1 0}$ & 2 & 459 & 6.58 \\
$\mathbf{1 5}$ & 2 & 716 & 10.27 \\
Total & $\mathbf{1 9}$ & $\mathbf{6 , 9 7 1}$ & $\mathbf{1 0 0 . 0 0}$ \\
\hline
\end{tabular}

Table 12 indicates the source of the solar panels (or modules) used in the projects that comprise the securitized portfolio. Diversity of solar panel manufacturers can be important to mitigate the potential for wide-scale manufacturing defects. Investors and rating agencies will normally consider the financial strength and/or insurance backing of each manufacturer to be certain that they can replace defective panels throughout the project life in case of wide-scale panel failure.

Table 12. SolarCo 2014-2 Distribution of Source of Solar Panels by Manufacturer

\begin{tabular}{llll}
\hline $\begin{array}{l}\text { Panel } \\
\text { Manufacturer }\end{array}$ & $\begin{array}{l}\text { No. of } \\
\text { Projects }\end{array}$ & $\begin{array}{l}\text { Aggregate Project } \\
\text { Size }\left(\mathbf{k W}_{\mathrm{DC}}\right)\end{array}$ & $\begin{array}{l}\text { \% of Aggregate } \\
\text { Project Size }\end{array}$ \\
ReneSola & 4 & 2,511 & 36.02 \\
Trina Solar & 5 & 2,082 & 29.87 \\
Canadian Solar & 2 & 680 & 9.75 \\
Yingli Solar & 1 & 678 & 9.72 \\
\hline Schueco & 4 & 633 & 9.08 \\
SunTech & 2 & 343 & 4.92 \\
Solar World & 1 & 44 & 0.63 \\
\hline Total & $\mathbf{1 9}$ & $\mathbf{6 , 9 7 1}$ & $\mathbf{1 0 0 . 0 0}$ \\
\hline
\end{tabular}




\subsection{Bond Structure and Notes}

The C\&I payment waterfall featured 15 different steps, as detailed in Figure 11.

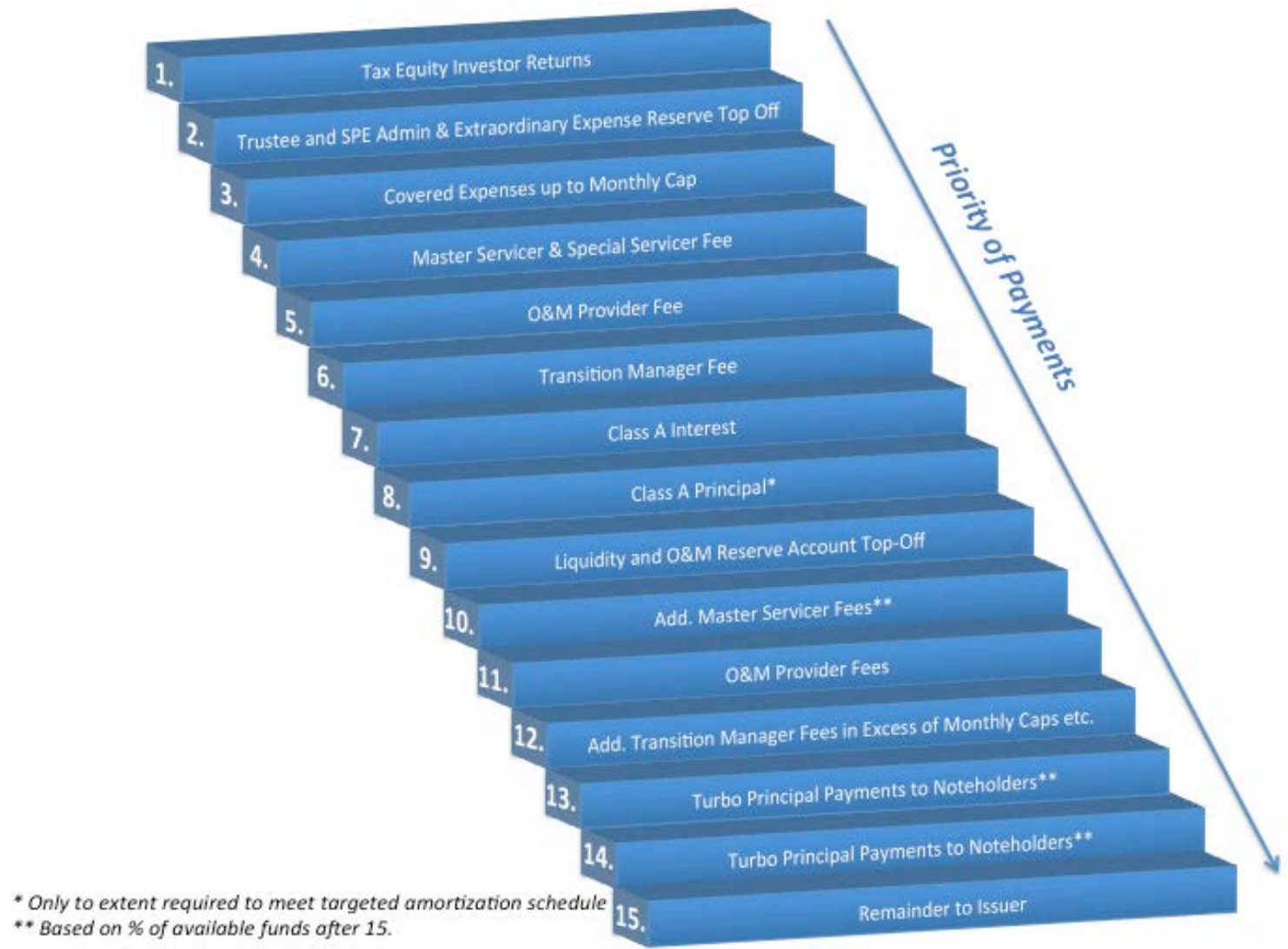

Figure 11. C\&I securitization payment waterfall

The characteristics of the notes issued against the C\&I portfolio of assets is detailed in Table 13 below.

Table 13. Summary of Hypothetical Notes Issued in C\&I Transaction

\begin{tabular}{ll}
\hline Note Issuance Amount & $\$ 15,373,650$ \\
\hline Note Structure & Fixed-rate, single class of amortizing notes \\
\hline Coupon Rate & $4.50 \%$ \\
\hline Overcollateralization & $25 \%$ \\
Debt Service Coverage Requirement & $1.2 x$ or greater \\
Liquidity Reserve & 6 months \\
Target Average Life & 6.43 years \\
Target Final Maturity & October 2025 \\
SEC Exemption & $144 \mathrm{~A}$ \\
Use of Proceeds & Retire bridge (warehouse) loans \\
Assumed Credit Rating & $\mathrm{A}$ \\
\hline
\end{tabular}

Lastly, as mentioned, the C\&I mock did not receive the same degree of cash-flow analysis as did the residential mock for reasons stated earlier in the report. Accordingly, only four stress cases were run; results are displayed in Table 14. 
Table 14. SolarCo 2014-2 Liabilities Scenarios

\begin{tabular}{|c|c|c|c|c|}
\hline & \multicolumn{4}{|c|}{ Scenario Name } \\
\hline & 2014-2 Base Cash Flows & $\begin{array}{l}98 \% \text { of } 2014-2 \text { Base } \\
\text { Cash Flows }\end{array}$ & $\begin{array}{l}96 \% \text { of } 2014-2 \text { Base Cash } \\
\text { Flows }\end{array}$ & $\begin{array}{l}31 \% \text { of } 2014-2 \text { Base Cash } \\
\text { Flows }\end{array}$ \\
\hline Discount Rate & $6.00 \%$ & $6.00 \%$ & $6.00 \%$ & $6.00 \%$ \\
\hline Prepayments & $0.00 \%$ & $0.00 \%$ & $0.00 \%$ & $0.00 \%$ \\
\hline $\begin{array}{l}\text { Cumulative } \\
\text { Interruption Loss }\end{array}$ & $0.00 \%$ & $4.42 \%$ & $8.83 \%$ & $64.04 \%$ \\
\hline O\&M Fees & $\$ 16 / \mathrm{kW}_{\mathrm{DC}} /$ year+1\% & $\$ 16 / \mathrm{kW}_{\mathrm{DC}} /$ year+1\% & $\$ 36 / \mathrm{kW}_{\mathrm{DC}} /$ year-1\% & $\$ 16 / \mathrm{kW}_{\mathrm{DC}} /$ year+1\% \\
\hline Servicing Fees & $\$ 14 / \mathrm{kW}_{\mathrm{DC}} /$ year+1\% & $\$ 14 / \mathrm{kW}_{\mathrm{DC}} /$ year+1\% & $\$ 14 / \mathrm{kW}_{\mathrm{DC}} /$ year+1\% & $\$ 14 / \mathrm{kW}_{\mathrm{DC}} /$ year+1\% \\
\hline $\begin{array}{l}\text { Tax-Equity } \\
\text { Investor Funds }\end{array}$ & $\$ 1,184,768.00$ & $\$ 1,184,768.00$ & $\$ 1,184,768.00$ & $\$ 1,184,768.00$ \\
\hline Class A WAL & 6.43 & 6.66 & 7.74 & 13.71 \\
\hline $\begin{array}{l}\text { Class Maturity } \\
\text { Date }\end{array}$ & October 2025 & March 2026 & January 2028 & October 2038 \\
\hline Class A Writedown & - & - & - & - \\
\hline Residual Funds & $\$ 18,350,001.52$ & $\$ 17,285,684.91$ & $\$ 13,809,984.41$ & $\$ 186,041.75$ \\
\hline
\end{tabular}




\section{Conclusion: Summary of Rating Agencies' Feedback}

The mock securitization project was a two-year iterative process that mobilized hundreds of volunteer-hours from SAPC participants to discern the current state of thinking amongst the credit-ratings agencies on solar-backed structured products. It was also an attempt to challenge that thinking, such that ratings agencies might become more familiar with solar as an asset class, thereby removing some barriers to higher credit ratings.

Since SAPC's initiation of the mock process, SolarCity has sponsored four securitizations thatwithout any specifics known to other SAPC members working on the mock securitization project — had apparently been in process for an extended period of time. No other solar installers or developers sponsored any securitizations during this same period, although Sunrun and AES have both come to market their own securities offerings since that time (there are also unverified reports that other sponsors are working on their own transactions as of this writing). Table 15 summarizes a few highlights of the four SolarCity securitizations and the Sunrun securitization. A number of capital market measurements show improved trends for solar developers over the period from November 2013 until July 2015, including: yield, offering size, required overcollateralization, and perhaps most importantly, the debt issuer advance rate. SolarCity's fourth securitization and Sunrun's first, both in July of 2015, received A ratings on their senior tranches from KBRA.

Table 15. Summary of SolarCity and Sunrun Securitizations

\begin{tabular}{|c|c|c|c|c|c|}
\hline & $\begin{array}{c}\text { SCTY I - } \\
\text { November } 2013\end{array}$ & $\begin{array}{l}\text { SCTY II - } \\
\text { April } 2014\end{array}$ & $\begin{array}{l}\text { SCTY III - } \\
\text { August } 2014\end{array}$ & $\begin{array}{c}\text { SCTY IV - July } \\
2015\end{array}$ & $\begin{array}{l}\text { Sunrun } \\
\text { Callisto - } \\
\text { July 2015-1 }\end{array}$ \\
\hline ABS Coupon Yield ${ }^{1}$ & $4.80 \%$ & $4.59 \%$ & $4.32 \%$ & $4.41 \%$ & $4.50 \%$ \\
\hline Bond Size & $\$ 54.4 \mathrm{~mm}$ & $\$ 70.2 \mathrm{~mm}$ & $\$ 201.5 \mathrm{~mm}$ & $\$ 123.5 \mathrm{~mm}$ & $\$ 111.0 \mathrm{~mm}$ \\
\hline $\begin{array}{l}\text { ADSCB } \\
\text { (present value of cash } \\
\text { flows) }\end{array}$ & $\$ 87.8 \mathrm{~mm}$ & $\$ 106.2 \mathrm{~mm}$ & $\$ 276.0 \mathrm{~mm}$ & $\$ 182.0 \mathrm{~mm}^{2}$ & $\$ 146.5 \mathrm{~mm}$ \\
\hline Overcollateralization \% & $38 \%$ & $34 \%$ & $27 \%$ & $32 \%$ & $24 \%$ \\
\hline $\begin{array}{l}\text { Advance Rate } \\
\text { (Bond size as \% of } \\
\text { ADSAB) }\end{array}$ & $62 \%$ & $66 \%$ & $73 \%^{3}$ & $68 \%{ }^{4}$ & $76 \%{ }^{5}$ \\
\hline $\begin{array}{l}\text { Senior Class A Notes } \\
\text { Rating }\end{array}$ & $\mathrm{BBB}+$ & $\mathrm{BBB}+$ & $\mathrm{BBB}+$ & $A(s f)$ & $A(s f)$ \\
\hline Rating Agency Utilized & S\&P & S\&P & S\&P & KBRA & KBRA \\
\hline
\end{tabular}

The SAPC working group was actively engaged with all the critical market participants across the timeline in Table 15, and provided a forum for these entities to exchange information. The working group's efforts to establish channels between the solar industry and players in the capital markets to increase open, largely untapped capital flows was an unprecedented collaboration, in terms of focus, scale, and contributor buy-in. 
Because rating agencies opine on credit risk but cannot advise issuers regarding how to structure their transactions, the ratings agencies had to exercise caution in the information they communicated about their positions vis-à-vis the solar asset class and in the feedback they provided on the mock portfolios. None of the agencies bestowed an "official" letter rating on the residential or C\&I mock filings. They were, however, forthcoming about their views regarding particular features and risks they perceived in the solar asset class, including:

- The specific business models used by the leading solar developers

- The technical aspects of solar technology and equipment

- Real and perceived risk variables affecting repayment likelihood

- Availability of performance data on system and obligor performance

- Policy and regulatory issues

- Cash-flow analytics and legal structures.

Table 16 summarizes the principal elements of feedback received from the rating agencies during the mock process. Mitigation efforts for several of the risks outlined below were undertaken by the SAPC working group and are now being actively explored in the market.

Table 16. Summary of Ratings Agency Feedback on the SAPC Mock Securitization Process

\begin{tabular}{|c|c|c|}
\hline Feedback & Issue & $\begin{array}{c}\text { Potential Action Steps by SAPC } \\
\text { and Market Participants }\end{array}$ \\
\hline $\begin{array}{l}\text { 13. Lack of } \\
\text { performance data }\end{array}$ & $\begin{array}{l}\text { - Limited solar production and } \\
\text { customer credit performance } \\
\text { data to estimate losses }\end{array}$ & $\begin{array}{l}\text { - Compile at least 3-5 years of } \\
\text { data on a meaningful sample of } \\
\text { systems and contracts } \\
\text { - Promote adoption of standard } \\
\text { contracts and system } \\
\text { performance measurements } \\
\text { - Establish uniform data-collection } \\
\text { procedures and data bases }\end{array}$ \\
\hline $\begin{array}{l}\text { 14. Issuer business- } \\
\text { model risk: } \\
\text { - Vertically vs. } \\
\text { non-vertically } \\
\text { integrated }\end{array}$ & $\begin{array}{l}\text { - Control and quality } \\
\text { standards } \\
\text { - Vertically integrated } \\
\text { companies may reduce risk } \\
\text { by controlling all aspects of } \\
\text { customer acquisition, system } \\
\text { design, installation and } \\
\text { operations and maintenance } \\
\text { (O\&M), billing and payment } \\
\text { processing, and investor } \\
\text { reporting } \\
\text { - Non-vertically integrated } \\
\text { companies may add risk if } \\
\text { critical functions are } \\
\text { outsourced and controls and } \\
\text { quality standards are not } \\
\text { enforced }\end{array}$ & $\begin{array}{l}\text { - Issuer/developers benefit from } \\
\text { clearly defining and } \\
\text { communicating the effectiveness } \\
\text { of their business model in } \\
\text { managing and enforcing quality } \\
\text { standards and business } \\
\text { practices, addressing how risk } \\
\text { from third-party vendors is } \\
\text { mitigated } \\
\text { - More industry information } \\
\text { needed to be able to identify and } \\
\text { quantify increased operational } \\
\text { risk in non-vertically integrated } \\
\text { business models }\end{array}$ \\
\hline
\end{tabular}




\begin{tabular}{|c|c|c|}
\hline Feedback & Issue & $\begin{array}{c}\text { Potential Action Steps by SAPC } \\
\text { and Market Participants }\end{array}$ \\
\hline $\begin{array}{l}\text { 15. Customer value } \\
\text { proposition for } \\
\text { third-party solar } \\
\text { contracts }\end{array}$ & $\begin{array}{l}\text { - Customers may perceive } \\
\text { greater value in new } \\
\text { contracts offering greater } \\
\text { savings, which could } \\
\text { increase defaults, payment } \\
\text { delays, and contract re- } \\
\text { negotiations } \\
\text { - Customer contract terms } \\
\text { vary by region and developer } \\
\text { - What assumptions are used } \\
\text { for energy costs over time } \\
\text { - What assumptions are used } \\
\text { for PV panel degradation }\end{array}$ & $\begin{array}{l}\text { - Transparency in customer } \\
\text { acquisition process and contract } \\
\text { assumptions } \\
\text { - Adoption of industry-created } \\
\text { standard contracts with standard } \\
\text { terms and conditions } \\
\text { - Greater standardization and } \\
\text { adoption of energy cost } \\
\text { production and savings } \\
\text { methodology } \\
\text { - Shorter lease/contract terms }\end{array}$ \\
\hline $\begin{array}{l}\text { 16. 20-year contract } \\
\text { terms }\end{array}$ & $\begin{array}{l}\text { - Long contract terms } \\
\text { introduce too much } \\
\text { uncertainty } \\
\text { - Energy and regulatory } \\
\text { landscape expected to } \\
\text { change dramatically } \\
\text { - Unable to reasonably predict } \\
\text { or quantify impact on } \\
\text { payment performance }\end{array}$ & $\begin{array}{l}\text { - If possible, shorten the length of } \\
\text { contract terms } \\
\text { - Structure securitization debt with } \\
\text { shorter maturity ( } 7-10 \mathrm{yrs})\end{array}$ \\
\hline $\begin{array}{l}\text { 17. Value of } \\
\text { equipment } \\
\text { warranty }\end{array}$ & $\begin{array}{l}\text { - Manufacturer warranty } \\
\text { obligations cannot be valued } \\
\text { in a securitization } \\
\text { - Most manufacturers are not } \\
\text { rated and no credit is given } \\
\text { to payment obligations } \\
\text { - Warranty terms vary by } \\
\text { manufacturer and equipment } \\
\text { type } \\
\text { - Not feasible to assess } \\
\text { various warranty coverages } \\
\text { for every system in a } \\
\text { securitization pool }\end{array}$ & $\begin{array}{l}\text { - Quantify risk and establish } \\
\text { reserve fund in securitization to } \\
\text { cover potential expense }\end{array}$ \\
\hline $\begin{array}{l}\text { 18. Operations and } \\
\text { maintenance of } \\
\text { systems in } \\
\text { securitized pool }\end{array}$ & $\begin{array}{l}\text { - Is the O\&M provider a rated } \\
\text { and creditworthy entity? } \\
\text { - If not, what happens if O\&M } \\
\text { provider fails to perform? } \\
\text { - How will the systems be } \\
\text { monitored and maintained? } \\
\text { - What companies exist with a } \\
\text { national footprint and } \\
\text { financially capable of } \\
\text { assuming these } \\
\text { responsibilities? } \\
\text { - What is the cost of transition } \\
\text { and the ongoing } \\
\text { maintenance? } \\
\text { - Can the securitization cash } \\
\text { flows support these costs? }\end{array}$ & $\begin{array}{l}\text { - More emphasis on identifying } \\
\text { O\&M service providers that meet } \\
\text { credit market standards } \\
\text { - Adoption of O\&M best practices } \\
\text { and standards } \\
\text { - More cost transparency by } \\
\text { participating in industry O\&M } \\
\text { databases and cost calculators } \\
\text { - Structure securitizations to } \\
\text { include market rate fees for O\&M } \\
\text { services and specific procedures } \\
\text { for back-up O\&M providers }\end{array}$ \\
\hline
\end{tabular}




\begin{tabular}{|c|c|c|}
\hline Feedback & Issue & $\begin{array}{c}\text { Potential Action Steps by SAPC } \\
\text { and Market Participants }\end{array}$ \\
\hline $\begin{array}{l}\text { 19. Inverter } \\
\text { replacement and } \\
\text { performance }\end{array}$ & $\begin{array}{l}\text { What are the assumptions } \\
\text { about inverter replacement } \\
\text { timing and cost? } \\
\text { - What types of inverters are } \\
\text { in the pool? } \\
\text { - What manufacturers are } \\
\text { represented? } \\
\text { - Are securitization cash flows } \\
\text { sufficient to pay for inverter } \\
\text { replacement? }\end{array}$ & $\begin{array}{l}\text { - Increase transparency about } \\
\text { inverter technology and } \\
\text { performance } \\
\text { - Establish standard performance } \\
\text { and cost measurements to } \\
\text { facilitate quantifying cost for } \\
\text { securitizations } \\
\text { - Securitization structure provides } \\
\text { cash flow and reserves for } \\
\text { inverter replacement and other } \\
\text { O\&M expenses not paid by O\&M } \\
\text { provider sufficient to replace } \\
\text { inverters according to a } \\
\text { conservative schedule based on } \\
\text { credible data for each type and } \\
\text { manufacturer }\end{array}$ \\
\hline $\begin{array}{l}\text { 20. System equipment } \\
\text { quality and } \\
\text { performance } \\
\text { reliability }\end{array}$ & $\begin{array}{l}\text { - Securitization pool systems } \\
\text { built with equipment from } \\
\text { different manufacturers and } \\
\text { potentially different } \\
\text { installation procedures } \\
\text { - Limited standards or quality- } \\
\text { assessment rating for PV } \\
\text { panels } \\
\text { - Installation practices vary } \\
\text { and may reduce equipment } \\
\text { performance } \\
\text { - Manufacturer warranty may } \\
\text { not pay for total cost of labor } \\
\text { and replacement }\end{array}$ & $\begin{array}{l}\text { - Prepare a detailed report } \\
\text { outlining manufacturers and } \\
\text { equipment selection process } \\
\text { - Standardize O\&M process and } \\
\text { provide reporting and } \\
\text { documentation } \\
\text { - Validate equipment output, } \\
\text { performance rating, and track } \\
\text { record } \\
\text { - Establish experience of and } \\
\text { credit quality of manufacturers } \\
\text { - Use insurance products to cover } \\
\text { manufacturer warranty obligation } \\
\text { and potential cash-flow shortfall } \\
\text { to the investors } \\
\text { - Establish reserve fund to cover } \\
\text { potential cash-flow shortfalls }\end{array}$ \\
\hline $\begin{array}{l}\text { 21. Role of } \\
\text { independent } \\
\text { engineering firms } \\
\text { in securitization } \\
\text { analysis }\end{array}$ & $\begin{array}{l}\text { - Industry and business } \\
\text { models in solar are too } \\
\text { young and rapidly evolving to } \\
\text { rely on standard asset due- } \\
\text { diligence techniques. } \\
\text { - A comprehensive } \\
\text { independent engineering } \\
\text { due-diligence report is } \\
\text { needed to identify and } \\
\text { quantify risks for } \\
\text { securitization cash-flow } \\
\text { analysis }\end{array}$ & $\begin{array}{l}\text { - Promote transparency in all } \\
\text { aspects of solar value chain } \\
\text { starting from the equipment } \\
\text { manufacturing through asset and } \\
\text { customer management } \\
\text { - Work with the IE community to } \\
\text { standardize system performance } \\
\text { measurements and promote } \\
\text { industry best practices to build } \\
\text { credibility for using statistical } \\
\text { sampling due-diligence practices }\end{array}$ \\
\hline $\begin{array}{l}\text { 22. Credit } \\
\text { enhancement }\end{array}$ & $\begin{array}{l}\text { - Is overcollateralization the } \\
\text { only available source of } \\
\text { credit enhancement for a } \\
\text { solar securitization? }\end{array}$ & $\begin{array}{l}\text { - Promote development of } \\
\text { alternative sources of credit } \\
\text { enhancement in the insurance } \\
\text { and financial services industries }\end{array}$ \\
\hline
\end{tabular}




\begin{tabular}{|c|c|c|}
\hline Feedback & Issue & $\begin{array}{c}\text { Potential Action Steps by SAPC } \\
\text { and Market Participants }\end{array}$ \\
\hline $\begin{array}{l}\text { 23. Tax-equity } \\
\text { investors and } \\
\text { securitization }\end{array}$ & $\begin{array}{l}\text { - Can securitization and tax } \\
\text { equity co-exist in financing a } \\
\text { pool of solar assets? } \\
\text { - Does the securitization } \\
\text { increase the risk of recapture } \\
\text { for the tax-equity investor? } \\
\text { - Do the securitization } \\
\text { investors have the same } \\
\text { security interest and } \\
\text { protection they would have in } \\
\text { financing without tax equity? }\end{array}$ & $\begin{array}{l}\text { - By using certain legal structures } \\
\text { for the tax-equity investment and } \\
\text { the securitization, tax equity and } \\
\text { securitization can co-exist in } \\
\text { financing a pool of commercial } \\
\text { solar assets (see link to tandem } \\
\text { tax-equity and securitization term } \\
\text { sheet) }\end{array}$ \\
\hline $\begin{array}{l}\text { 24. Cash-flow } \\
\text { modeling }\end{array}$ & $\begin{array}{l}\text { Devising cash-flow modeling } \\
\text { for new or esoteric asset } \\
\text { classes includes input from } \\
\text { and analysis performed by } \\
\text { leading independent } \\
\text { engineering firm(s). A } \\
\text { meaningful independent IE } \\
\text { report on a hypothetical solar } \\
\text { portfolio and transaction } \\
\text { structure was not possible. }\end{array}$ & $\begin{array}{l}\text { - Be prepared for and have } \\
\text { available detailed due-diligence } \\
\text { analysis and reports to inform } \\
\text { rating agencies about the } \\
\text { issuer/sponsor's business model } \\
\text { and value proposition, customer } \\
\text { acquisition, underwriting and } \\
\text { origination process } \\
\text { - Solar system design, equipment, } \\
\text { and quality control and historical } \\
\text { performance statistics about } \\
\text { energy output compared to } \\
\text { expected output, energy contract } \\
\text { payment experience and } \\
\text { statistics } \\
\text { - O\&M process, experience and } \\
\text { costs } \\
\text { - Other asset-management and } \\
\text { risk-mitigation processes and } \\
\text { procedures. }\end{array}$ \\
\hline
\end{tabular}




\section{Appendix A: Securitization Background}

\section{The U.S. Securitization Market}

"Securitization" refers to the process of structuring revenue-generating assets for issuance and sale into the capital markets as rated securities. The U.S. securitization market can be broadly divided into two categories: mortgage-backed securities (MBS) and asset-backed securities (ABS).

- MBS transactions are generally backed by residential or commercial mortgages. (MBS transactions backed by commercial mortgages are generally referred to as commercial mortgage-backed securities or CMBS.)

- ABS cover virtually all other types of securitized debt, including transactions backed by non-real estate assets, as well as certain securitizations backed by real-estate assets but structured differently from MBS or CMBS.

Since the 1970s, when MBS were pioneered, the securitization market has grown to comprise a large portion of the overall U.S. capital markets, representing about $25 \%-30 \%$ of all fixedincome securities outstanding over the past decade. It is a deep and liquid market capable of connecting issuers who meet certain parameters to large swaths of institutional investors.

Overall securitization issuance peaked in 2003 at over $\$ 3.5$ trillion and by 2007 annual issuance volume was about $\$ 2.75$ trillion. Between the financial collapse in 2008 and 2010, the securitization new-issuance volumes remained relatively low. Through 2013, the market has gradually recovered to the point that annual issuance volume is at about $\$ 2$ trillion per year (Figure A-1). The ABS market, as distinguished from the overall securitization market, peaked later (in 2005), and annual ABS issuance volume stayed between $\$ 250$ billion and $\$ 300$ billion until 2008. After the financial crisis, ABS began recovering again in 2012 and 2013 to stabilize around $\$ 200$ billion annually. The majority of outstanding ABS (55\%) is currently rated A or above (Figure A-2). All data and figures below are from the Securities Industry and Financial Markets Association (SIFMA). ${ }^{12}$

\footnotetext{
${ }^{12}$ The SIFMA "Statistics" page can be found at http://www.sifma.org/research/
} 


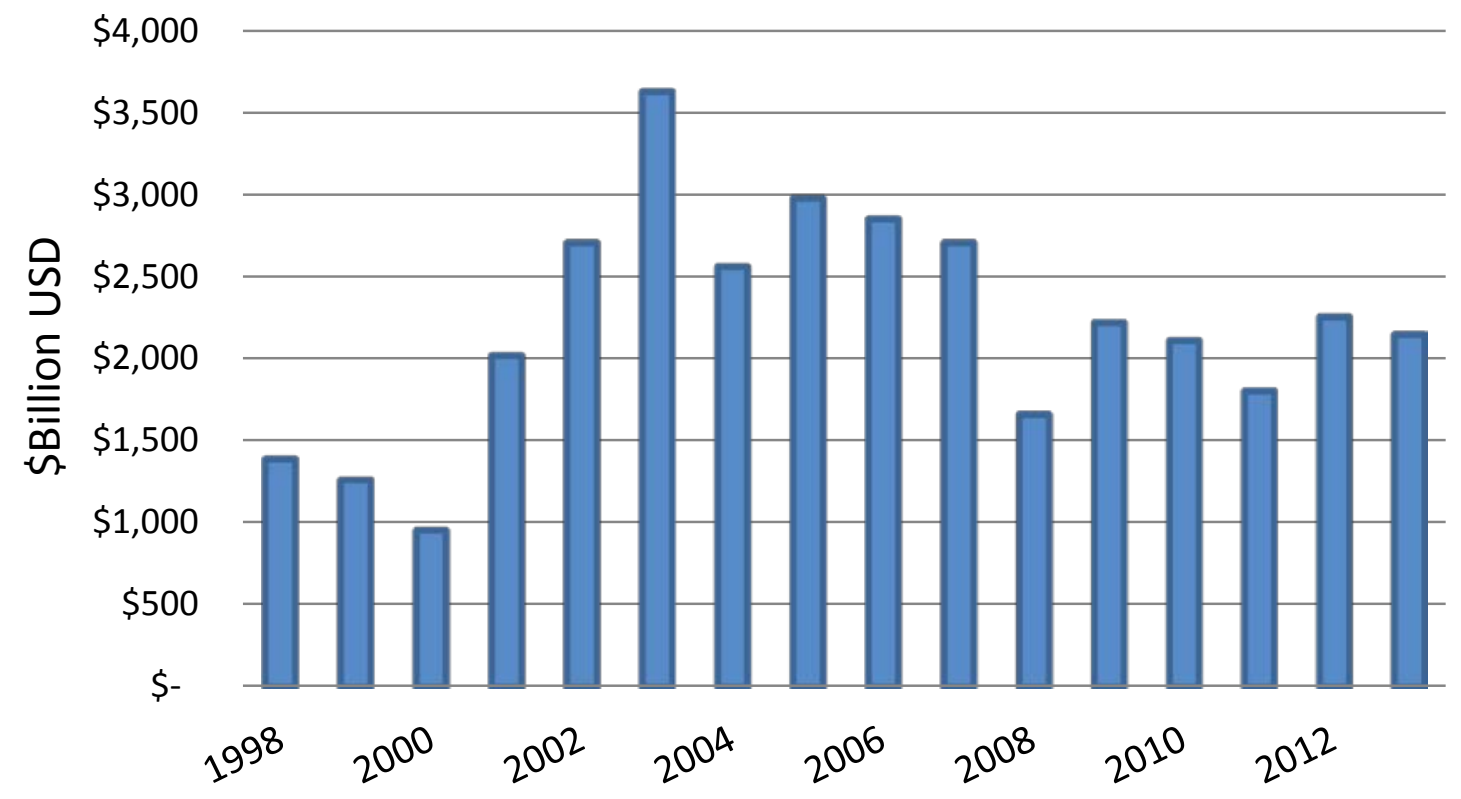

Figure A-1. Total securitized debt issuance, 1998-2013

Source: SIFMA "U.S. ABS Issuance and Outstanding"

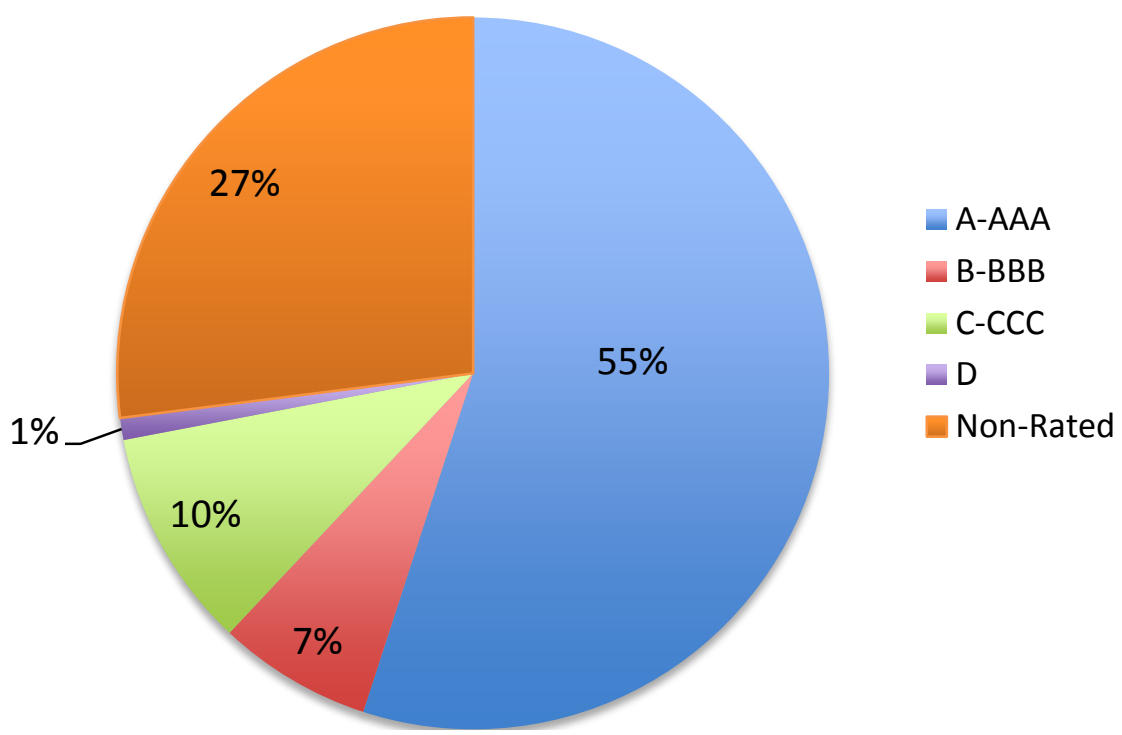

Figure A-2. ABS outstanding by credit rating

Source: SIFMA "U.S. ABS Issuance and Outstanding"

Total global securitization issuance in 2014 was $\$ 1.932$ trillion. Total U.S. securitization issuance volume in 2014 was $\$ 1.504$ trillion, of which mortgage-related securities represented $85 \%$. Total U.S. ABS issuance volume in 2014 was $\$ 225.4$ billion. Of the total U.S. ABS issuance volume in 2014, auto loans comprised $42.7 \%$, credit card receivables was $23.4 \%$, 
equipment was $7.83 \%$, housing-related assets was $9.49 \%$, student loans was $6.25 \%$, and $10.24 \%$ was categorized as "other."

The largest issuers of MBS are the government-sponsored entities ("GSEs"): Governmental National Mortgage Association (GNMA or "Ginnie Mae"), Federal National Mortgage Association (FNMA or "Fannie Mae"), and Federal Home Loan Mortgage Corporation (FHLMC or "Freddie Mac"). ${ }^{13}$ In the years leading up to the financial collapse in 2008, banks and specialty finance companies also issued so-called "private label" MBS. However, since 2008, the private-label MBS market has been virtually non-existent. Typical MBS investors include pension funds and hedge funds.

\section{The Process of Securitization}

In a typical securitization structure, there is an operating company that has originated the assets being securitized, known as the "Originator." The originator typically sells or contributes the assets in question either directly to a single-purpose bankruptcy-remote entity (usually organized as either a Delaware limited liability company or as a Delaware trust), which will serve as the issuer of the asset-backed securities (the "Issuer"). In other cases, the originator sells or contributes the assets into an interim ownership entity (the "Depositor"), and the depositor in turn sells or contributes the assets to the issuer. Under either structure, an opinion is rendered to the effect that the transfer by the originator constitutes a "true sale" for bankruptcy law purposes. In a true sale, the originator legally transfers the securitized assets in a completed arm's-length transfer to a new entity, and removes itself from any liens or other legal liabilities. In addition, another legal opinion is usually required to the effect that the Issuer will not be consolidated with the originator in the event of an originator bankruptcy.

In connection with the issuance of the asset-backed securities (usually in the form of notes) by the issuer, the issuer will execute a trust indenture ("Indenture") with an institutional trustee as indenture trustee. Under the terms of the indenture, the assets and all other rights associated therewith are pledged by the issuer to the indenture trustee for the benefit of the noteholders, and the indenture trustee agrees to allocate and distribute the cash flows received with respect to the pledged assets under a priority of payments provided under the indenture. Reserve funds are also established and funded under the indenture.

The operating company, or originator, will also often contract under a separate management or servicing agreement with the issuer and the indenture trustee to collect the cash flows relative to the securitized assets and otherwise manage the assets while the securitization notes are outstanding. There will often be a back-up servicer or manager that will be available to take over the duties of the manager/servicer in the event of the default or other inability of the manager/servicer to perform its duties, or a sub-manager/servicer that will, from the date of issuance of the notes, assume on a sub-contract basis from the originator as the master manager/servicer certain management or servicing responsibilities with respect to the securitized assets. In addition to the Manager/Servicer, where the collateral for the securitization includes equipment, there is often included in the securitization structure an operations and maintenance

\footnotetext{
${ }^{13}$ GSEs are designed to facilitate homeownership either broadly or among specific sectors of the U.S. population through the availability of long-term loans.
} 
service provider (“O\&M Provider”), who is responsible for day-to-day operation and maintenance of the equipment. Finally, it is becoming more typical in securitizations of assets that require a certain level of day-to-day management to have the indenture trustee contract with a bank or other financial institution (the "Transition Manager") to perform certain transition management services on those occasions when it is necessary to assign the management/servicing functions to another party.

\section{The Ratings Process}

Rating agencies opine on the future creditworthiness of transactions. MBS and ABS investors generally expect review by one or more rating agencies. Issuers generally seek ratings that are high enough to attract investors at interest rates lower than traditional bank debt. These lower interest rates have been the principal reason that issuers are attracted to securitization. The structural components that makes it possible for companies with no or very low ratings to transform unrated assets into highly rated securities has been practiced for over forty years. Although the process can be more complex, time-consuming, and expensive than issuing traditional secured or unsecured debt, Originators have endured these burdens to issue highly rated securities in order to realize these benefits.

To obtain the ratings desired, assets being securitized must be isolated from the risk of bankruptcy of the Originator. This is done by transferring the assets into a SPV, which possesses certain structural features that decrease the chance that the SPV will be the subject of a bankruptcy proceeding while the rated debt is outstanding. In addition, to be attractive to institutional investors, the securities should generally be issued in a sufficiently large principal amount to permit multiple institutional investors to invest in them. This creates greater opportunities for buying and selling the securities in the secondary (i.e., post-issuance) market, resulting in greater liquidity. (Greater liquidity usually results in lower interest rates on the securities.) The function of rating agencies in this process is to assess the risk that any of the securities will not be paid on the schedule specified in the transaction documents.

A strong investment-grade rating of a debt security will likely result in a reduction in the interest rate at which an investor will buy the security, thus producing benefits to the issuer in the form of lower debt service costs and higher advance rates (the ratio of debt raised to the discounted present value of the cash flows from the underlying collateral).

In the rating process, rating agencies do not assist issuers in structuring their deals; an agency will only analyze structures that issuers place before it. Depending on how the rating agencies view the proposed deal, an issuer may need either more or less overcollateralization (credit enhancement) to achieve a desired rating. ${ }^{14}$ Overcollateralization refers to the "cushion" in the form of either pledged cash flow in excess of debt service requirements or the addition of subordinated classes of debt. In either case, the issuer's objective is to achieve the lowest cost of funds by minimizing the amount of overcollateralization or subordination levels and to maximize the principal amount of the highest rated securities in the offering.

\footnotetext{
${ }^{14}$ Although rating agencies do not advise issuers on the structure any specific issuance, as part of their review of a proposed deal, the rating agencies may provide feedback on the perceived credit risks associated with the structures proposed for their review.
} 